University of Rhode Island

DigitalCommons@URI

Open Access Master's Theses

1996

\title{
Molecular Genetic Analysis of Senescence and the Reversal of Senescence in Soybean Cotyledons [Glycine max (L.) Bass]
}

Normand Edouard Allaire

University of Rhode Island

Follow this and additional works at: https://digitalcommons.uri.edu/theses

\section{Recommended Citation}

Allaire, Normand Edouard, "Molecular Genetic Analysis of Senescence and the Reversal of Senescence in Soybean Cotyledons [Glycine max (L.) Bass]" (1996). Open Access Master's Theses. Paper 1040. https://digitalcommons.uri.edu/theses/1040

This Thesis is brought to you for free and open access by DigitalCommons@URI. It has been accepted for inclusion in Open Access Master's Theses by an authorized administrator of DigitalCommons@URI. For more information, please contact digitalcommons-group@uri.edu. 


\author{
MOLECULAR GENETIC ANALYSIS OF SENESCENCE \\ AND THE REVERSAL OF SENESCENCE \\ IN SOYBEAN COTYLEDONS \\ [Glycine max (L.) Bass] \\ BY \\ NORMAND EDOUARD ALLAIRE
}

A THESIS SUBMITTED IN PARTIAL FULLFILLMENT OF THE REQUIREMENTS FOR THE DEGREE OF

MASTERS OF SCIENCE

IN

BIOLOGICAL SCIENCES

UNIVERSITY OF RHODE ISLAND

1996 


\section{MASTER OF SCIENCE THESIS}

OF

NORMAND EDOUARD ALLAIRE

\section{APPROVED:}

Thesis Committee

Major Professor

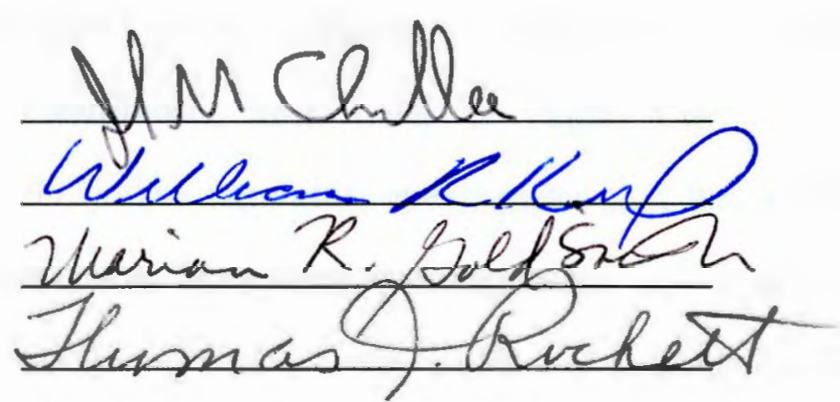

DEAN OF THE GRADUATE SCHOOL 


\section{ABSTRACT}

Whole plant senescence is a programmed, endogenously controlled process in which cellular components are degraded and the resultant metabolites sequestered to other plant organs. All cells, with the possible exception of the meristem progenitors, go through cell division, expansion, elaboration of secondary structures to the primary cell wall, quiescence, and finally death. This senescence process is thought to be partially catalyzed by an increase in translation of degradative proteins coupled to a decrease in translation of vital proteins (Skadsen and Cherry, 1983). Inducers of senescence include wounding, fruit ripening, changes in hormone levels (auxin, cytokinins + auxin, $\mathrm{Ca}^{2+}+$ cytokinins, and ethylene), various stresses (anaerobiosis, heat, cold, UV light, $\mathrm{Cd}^{2+}$, and $\mathrm{Li}^{+}$), and pathogen attack (Theologis, 1992). The regulatory mechanisms that facilitate entry of a cell, tissue, or whole plant into this final developmental stage are largely unknown; however, hormonal controls are likely to be involved. A better understanding of the genetic regulation of senescence will be important for studies relating to: 1) normal cellular differentiation, maintenance, and turnover; 2) plant defense mechanisms and the hypersensitive response; and 3) embryogenesis and development. In addition, economic benefits could result from reduction in post-harvest and post-production losses as well as improvement of crop yields.

Evidence indicates that soybean cotyledon senescence and induced "rejuvenation" (i.e.,. the reversal of the senescence process) are associated with changes in gene expression (Marek and Stewart 1992; Skadsen and Cherry 1983). During germination the cotyledons emerge, become green, and develop leaf-like characteristics including photosynthetic and storage mobilizing capability. During normal development, the cotyledons senesce after expansion of the first and second trifoliates. It has been shown (Krul, 1974) that this process can be reversed by the removal of the epicotyl up to the 
"point of no return" (PONR), a developmental stage at which up to $90 \%$ of nucleic acids and $80 \%$ of proteins are lost from the senescing cotyledon.

The objectives of this research project were to identify genes that show differential expression during senescence and rejuvenation in the soybean cotyledon system and to isolate clones of genes that are specifically up-regulated in expression during these processes. To accomplish these objectives, Northern blots were used to assay soybean cotyledon mRNA populations during various stages of senescence and rejuvenation using a collection of gene clones known or suspected to be involved in senescence and rejuvenation. These gene clones included: 1) a tomato ethylene forming enzyme (EFE) and several other ethylene up-regulated genes; 2) from carnation, ACC synthase, glutathione stransferase and other unidentified senescence associated genes; 3) from soybean, three lipoxygenases, two vegetative storage proteins, rubisco large and small subunits and an iron superoxide dismutase; 4) from cucumber, malate synthase and isocitrate lyase; and 5) two Arabidopsis genes, Sag2 (cysteine protease) and Sag4 (currently unidentified). In addition, cDNA libraries were constructed from senescent, nonsenescent, and rejuvenated soybean cotyledons. Finally, a cDNA library made from senescing soybean cotyledons was screened for a Sag2 homologue.

These studies revealed up-regulation in expression during cotyledon senescence for rubisco large and small subunits, two soybean vegetative storage proteins, and an Arabidopsis cysteine protease. A soybean homologue to the Arabidopsis cysteine protease (Sag2) was cloned from senescing soybean cotyledons and restriction analysis revealed that it contained two PvuII sites. 


\section{ACKNOWLEDGEMENTS}

I wish to express my appreciation to Dr. Joel M. Chandlee for his guidance during my graduate studies and without his help this manuscript would not have been completed. I would also like to thank the other members of the committee: Dr. Marion R. Goldsmith, Dr. William Krul, and Dr. Anthony Fischl.

Many friends and family members, too numerous to list, have supported me during and beyond my graduate studies. I would like to extend my gratitude to my mother and father, brothers and sisters, Richard, Genevieve, John, and Andree, Fellow students: Chung, Pang, Lee Ju, Jian, Maureen, Ji, and Sardha, and friends: Steve Neri, Tim Morse, Tony Fischl, Katie Gilbert.

During my graduate studies I came across some quotes that I found were particularly suited to my graduate experience:

You know I've made mistakes, I've had my ups and downs, my ins and outs and my share of bad breaks, but when all been said and done, I raise my beer and I swear "God it's been fun".

Drunks and Children

The Mighty Mighty Bostones

Bob's your uncle.

Tim Morse (The Timinator)

Finally,

This thesis is dedicated to the memory of my mother who died in the spring of 1993. 


\section{PREFACE}

This thesis has been prepared in the manuscript format. Manuscript I, "Differential Gene Expression During Senescence and The Reversal of Senescence in Soybean Cotyledons," and Manuscript II, "Isolation of a Soybean cDNA Clone With Homology To Sag2, a Senescence-Associated Gene From Arabidopsis," have been prepared and will be submitted for publication in Plant Physiology. 


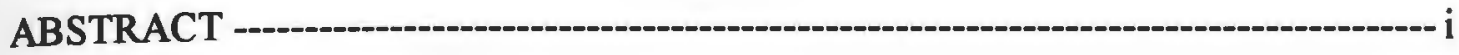

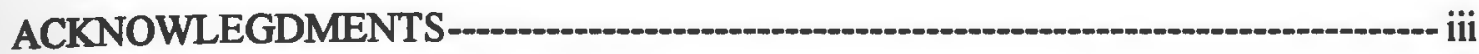

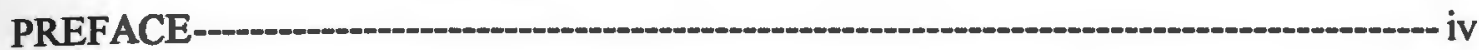

LIST OF TABLES -

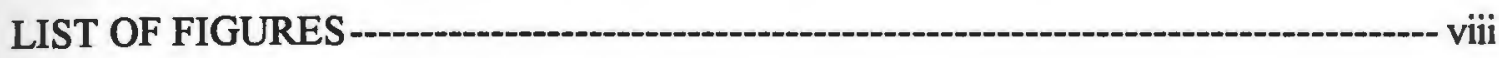

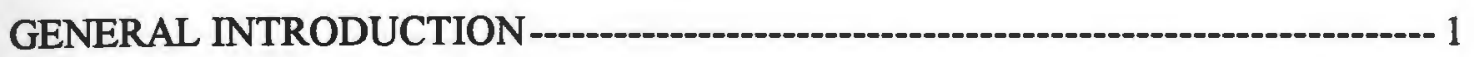

A. Senescence - 1

1) Overview of Senescence -------------------------------------------------- 1

Historical Perspective of Senescence Research

Senescence versus Aging

2) Regulation of Senescence by Plant Hormones

Ethylene

Cytokinins

Other Hormones

3) Model Systems for Molecular Genetic Analysis of Senescence -.----- 4

Fruit Ripening

Flower Petals

Leaves

B. Soybean Cotyledons as a Model System For Investigations of Senescence and The Reversal of Senescence ---_-_-_-_- 7

C. Rationale and Significance -

MANUSCRIPT I: Differential Gene Expression During Senescence and

TheReversal of Senescence in Soybean Cotyledons 


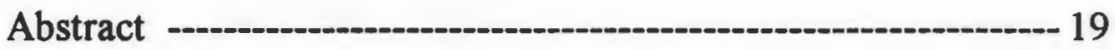

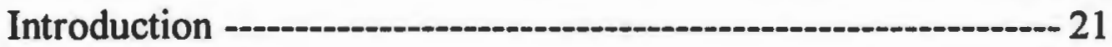

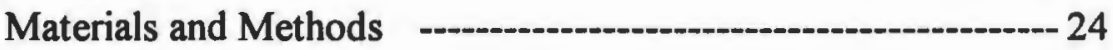

Plant Materials

Extraction and Purification of RNA

Northern Blot Analysis

Probe Preparation

Results

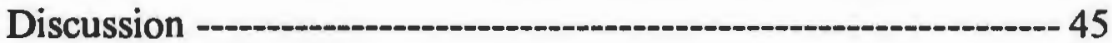

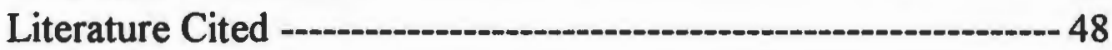

MANUSCRIPT II: Isolation Of A Soybean cDNA Clone With Homology

To Sag2, A Senescence-Associated Gene from Arabidopsis ---- 52

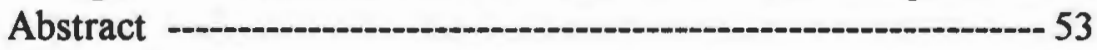

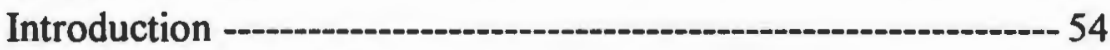

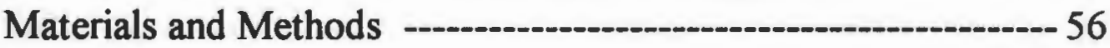

Plant Materials

Extraction and Purification of Total RNA and mRNA

Probe Preparation

cDNA Library Contraction and Screening

Characterization of Homologous Clones

Results

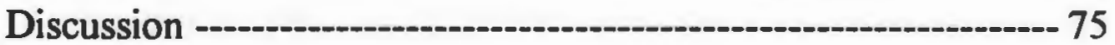

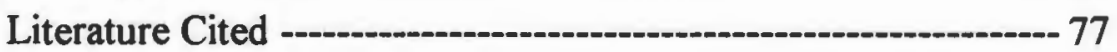

GENERAL DISCUSSION - 80

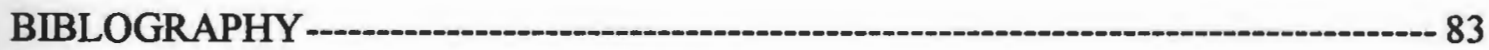




\section{LIST OF TABLES}

MANUSCRIPT I

Page

Table 1. Gene Probes Assayed Using Northern Analysis 27 


\section{LIST OF FIGURES}

MANUSCRIPT I

Page

Figure 1. Northern blot of cotyledon total RNA populations from different developmental stages using CARACC3 (ACC synthase from carnation petals) as a gene specific probe.

Figure 2. Northern blot of cotyledon total RNA populations from different developmental stages using rbcL (ribulose 1-5 bis phosphate carboxylase, oxygenase from soybean) as a gene specific probe.

Figure 3. Northern blot of cotyledon total RNA populations from different developmental stages using Sag2 (cysteine protease from Arabidopsis) as a gene specific probe.

Figure 4. Northem blot of cotyledon total RNA populations from different developmental stages using pVSP25 (Vegetative storage protein from carnation) as a gene specific probe.

Figure 5. Northern blot of cotyledon total RNA populations from different developmental stages using pVSP27 (Vegetative storage protein from carnation) as a gene specific probe. 


\section{LIST OF FIGURES}

MANUSCRIPT I

Page

Figure 6. Northern blot of cotyledon total RNA populations from different developmental stages using pUBS6 (Ubiquitin from soybean) as a gene specific probe.

Figure 7(a) Northern blot of cotyledon total RNA populations from different developmental stages using pSIC3e (Homologous clones of Sag2 from soybean cotyledons) as a gene specific probe.

(b) Northern blot of cotyledon total RNA populations from different developmental stages using pSIC10c (Homologous clones of Sag2 from soybean cotyledons) as a gene specific probe.

\section{MANUSCRIPT II}

Figure 1(a) $\quad 2^{\circ}$ Screen: Agarose gel electrophoresis of PCR amplification products from plaque isolates numbered 1 through 15 from the $1^{\circ}$ screen.

(b) $2^{\circ}$ Screen: Southern blot of figure la gel using Sag2 as a probe. 62

(c) $2^{\circ}$ Screen: Agarose gel electrophoresis of PCR amplification products from plaque isolates numbered 16 through 30 from the $1^{\circ}$ screen.

(d) $2^{\circ}$ Screen: Southern blot of figurelc gel using Sag2 as a probe. 64 


\section{LIST OF FIGURES}

MANUSCRIPT II

Page

Figure 2(a) $3^{\circ}$ Screen: Agarose gel electrophoresis of PCR amplification products from the $2^{\circ}$ screen.

(b) $3^{\circ}$ Screen: Agarose gel electrophoresis of PCR amplification products from the $2^{\circ}$ screen. 66

Figure 3(a) $\quad 4^{\circ}$ Screen: Agarose gel electrophoresis of PCR amplification products from plaque isolates numbered $3 \mathrm{a}, 3 \mathrm{~b}, 3 \mathrm{e}, 8 \mathrm{~b}, 8 \mathrm{e}, 9 \mathrm{e}$, $10 \mathrm{a}, 10 \mathrm{c}, 12 \mathrm{a}, 12 \mathrm{~b}, 14 \mathrm{~b}, 14 \mathrm{c}, 14 \mathrm{~d}, 22 \mathrm{~b}, 25 \mathrm{a}, 25 \mathrm{~b}, 25 \mathrm{c}, 25 \mathrm{~d}$, $25 \mathrm{e}$ from the tertiary screen 68

(b) $4^{\circ}$ Screen: Southern blot of figure 3a gel using Sag2 as a probe. 68

Figure 4(a) Northern blot of Sag2

(b) Northern blot of pSIC3e -

(c) Northern blot of pSIC10c - 71

Figure 5(a) Restriction maps of pSIC3e - 73

(b) Restriction maps of pSIC10c - 73 


\section{GENERAL INTRODUCTION}

\section{A. Senescence}

\section{1.) Overview of Senescence}

Senescence is a highly coordinated degenerative process that is characterized by a series of biochemical and physiological changes including increase in respiration, changes in hydrolytic enzyme activity, peroxidation of membrane lipids, and in some cases an increase in ethylene biosynthesis (Borochov et al., 1989). This process represents the final developmental stage of the organism, tissue, or cell from the mature fully expanded state until death (Smart et. al., 1995). Cells remain viable and show tight metabolic regulation throughout the senescence process (Thomas, 1992; Matile, 1992; Smart, 1994). Senescence is a metabolically active phase that requires transcription of new genes as well as down regulation of other genes (Skadsen and Cherry 1983).

Senescence includes, but is not limited to death of the whole plant. In some perennial species, senescence occurs in the portions of the plant that are above ground, but not in the bulb or the root. Deciduous woody plants lose their leaves but maintain the root system and all other above ground portions. A less dramatic example of senescence is the gradual loss of leaves from the base of the plant upward that is typical of many species. Senescence at the cellular level is part of an important developmental process as exemplified during fertilization, when the synergid that resides adjacent to the newly fertilized egg deteriorates as does the pollen tube that delivers the sperm cells to the unfertilized egg.

\section{Historical Perspective}

The idea that a process that leads to the death of a plant or its parts is under endogenous control is a relatively new concept. Molish in his classic work "The Longevity of Plants" (1938) was the first to clearly recognize that death might be actively induced by endogenous factors that are a natural part of an organism's development (Nooden et al., 
1988). Since this time the concept of senescence as an important developmental process has been gaining favor. More recent evidence indicates that senescence is an important developmental process in the life cycle of the plant (Sabater et al., 1989: Nooden, 1988; Hensel et al., 1993).

\section{Senescence versus Aging}

Senescence represents an active endogenously controlled process that leads to death of the plant, tissue, or cell. This contrasts strongly with the concept of aging. Aging encompasses a wide array of passive rather than active processes that appear to be unregulated and driven primarily by exogenous factors (Leopold, 1978). Senescence is a developmental process that always leads to death, whereas aging does not necessarily result in death.

\section{2.) Regulation of Senescence by Plant Hormones}

\section{Ethylene}

Ethylene is one of the simplest organic molecules with biological activity (Theologis, 1992). It has been implicated to play a major role as a fruit ripening hormone (Abeles, 1973). Ethylene is required for activation and maintenance of several genes involved in the process of fruit ripening and flower petal senescence (Brady, 1987; Christofferson et al., 1982; Holdsworth et al., 1987a; Holdsworth et al., 1987b; Meyer et al., 1991; Raghothama et al., 1991; Sato and Theologis, 1992; Theologis, 1992; Woodson, 1988; Yenofsky et al. 1988). Increases in respiration, inhibition of growth, modification of pigments, loss of geotropic sensitivity (Burg, 1962) and changes in gene expression have been observed in ethylene treated fruit (Davies et al., 1989; Holdsworth et al.,1987a; Holdsworth et al., 1987b). The biosynthetic pathway for ethylene production has been elucidated by Yang and his associates. The rate limiting step is catalyzed by 1aminocyclopropane-1-carboxylate synthase (ACC synthase) and the final step (conversion 
of ACC to ethylene) is catalyzed by ACC oxidase (Sato and Theologis., 1989). Genes for both ACC synthase and ACC oxidase have been cloned (Slater et al., 1985; Hamilton et al., 1991; Spanu et al., 1991).

\section{Cytokinins}

Cytokinins represent a class of plant hormones that play an important role in the regulation of plant senescence. Structurally, cytokinins are adenine derivatives with various N6-substituants (Bonner and Varner, 1976). Unlike ethylene, the biosynthetic pathway for cytokinin production has not been elucidated (Nooden, 1988). Although a lack of information exists regarding how cytokinins are synthesized, a great deal of information is known about the physiological effects and sites of production (Carr and Burrows, 1966; Kende, 1965; Kende, 1971; Short et al., 1972). Generally cytokinins are associated with senescence deferring properties. Specifically, cytokinins are associated with maintenance of chlorophyll, protein, and RNA levels (Richmond and Lang, 1957). Molish (1938) has shown that root formation greatly increases the life of excised leaves (Nooden, 1988). Kulaveva (1962) reported that cytokinin-like senescence retarding factors were produced by roots. Today it is widely accepted that roots are the major site of cytokinin production and that cytokinins are plant hormones that act to delay senescence.

\section{Other Hormones}

Other plant hormones have been implicated in the process of senescence, but few generalizations can be made about their effect on senescence. This is largely due to the fact that the other hormones have vastly different effects when applied to different tissues or on the same tissues at different stages of development. An example of the difficulty in assigning discrete roles to many hormones involved in senescence is illustrated by the 
naming of abscisic acid by its identification as an abscission-inducing factor; however, this is not true in many species (Klee and Ramano, 1994). In the case of auxin there are reports that applications of $\alpha$-naphthalene acetic acid retards the senescence of Rhoeo and Mesembryanthemum leaf segments (Sacher, 1959). Auxin is also known to stimulate production of ethylene in concentrations only slightly above physiological levels and ethylene promotes senescence in some species (Smart, 1994).

\section{3.) Model Systems for Use in the Molecular Genetic Analysis of Senescence}

Many model systems have been used for molecular genetic analysis of senescence in leaves, fruits, and flower petals (Chibnall, 1954; Davies and Grierson, 1989; DellaPenna, et al., 1986; Kende, 1965; Krul, 1974; Lawton, 1989; Sabater, et al., 1989; Skadsen and Cherry, 1983; Sort and Torrey, 1972). Up-regulation, down-regulation and homeostasis of particular gene expression patterns have been reported in all these systems (Bate, 1990; Brady, 1988; Cremer, 1990). Ethylene is an apparent trigger for mRNAs involved in senescence in carnation petals and various fruits (Davies and Grierson, 1989; Holdsworth, et al., 1987; Marek and Stewart, 1992; Rapp and Mullet, 1991; Theologis, 1992; Yenofsky, 1988). The function, if any, of any down-regulated genes during senescence remains unclear.

\section{Fruit Ripening}

Ethylene has been implicated as a major fruit ripening hormone. Increases in respiration, inhibition of growth, modification of pigments, and loss of geotropic sensitivity (Burg, 1962) and changes in gene expression have reported for ethylene treated fruit (Davies, Grierson, 1989; Holdsworth, et al., 1987a; Holdsworth, et al., 1987b). Ethylene is required for activation and maintenance of several genes involved in the process of fruit ripening (Brady, 1987; Christofferson, et al., 1982). Several up-regulated mRNAs have been identified that encode cell-wall softening enzymes, including 
polygalacturonase from tomato (Slater, 1985) and cellulase from avocado (Christofferson, 1984). The rate-limiting enzyme in ethylene biosynthesis is 1 aminocyclopropane-1carboxylic acid (ACC) synthase, and the final step for the conversion of ACC to ethylene is catalyzed by ACC oxidase.

\section{Flower Petals}

Carnation petals have been used as a model system for the study of senescence (Borochov and Woodson, 1989; Lawton, 1989; Meyer, et al., 1991; Peterman and Siedow, 1985; Rapp and Mullet, 1991; Woodson, 1988), which is associated with changes in cellular biochemistry and physiology. These changes have also been shown to be regulated in part by ethylene (Lawton, et al., 1989; Short, et al, 1988; Wang and Woodson, 1991). cDNA clones of ACC synthase, ACC oxidase, and glutathione-stransferase have been isolated from senescing carnation petals and should be useful in elucidating the regulatory mechanism of ethylene action (Mayer, et al, 1991; Peterman and Siedow, 1985; Wang and Woodson, 1991).

\section{Leaves}

Leaf senescence represents a programmed, highly coordinated degenerative process that results in the breakdown of cellular components and sequestering of the resultant metabolites to other plant organs. Recent evidence indicates that the ethylene signal in leaves is transduced via protein phosphorylation events and is mediated by specific kinases and phosphatases, however, such evidence does not exist for fruit (Rundle and Zielinski, 1991).

Ultrastructural analysis reveals that the degreening of mesophyll cells associated with a loss of thylakoid structures and increases in plastoglobuli are characteristics of the senescence syndrome in leaves (Thomson and Plat-Aloia, 1987). Coupled to the disruption of the thylakoid membrane is a decrease in photosynthesis due to a decrease in ribulose- 
1,5,-bisphosphate carboxylase/oxygenase and noncyclic electron transport (Bate, et al., 1990; Crafts-Brandner and Egli, 1987; Start et al., 1986; Thomson and Plat-Aloia, 1987). Similarities between leaf senescence and fruit ripening activities have been reported, including breakdown of the photosynthetic apparatus, degradation of starch and chlorophyll, stimulation of respiration, in some cases a burst of ethylene production (Aharoni and Liberman, 1979a; Aharoni and Liberman, 1979b; Thimann, 1980; Stoddart, 1980), and expression of at least some related genes (Davies and Grierson, 1989). Although leaf senescence is similar to fruit ripening, unique aspects have been identified (Aharoni and Liberman, 1979a; Aharoni and Liberman, 1979b; Bate, et. al., 1990). In soybean, the signals that are produced by developing seeds appear to induce monocarpic whole plant senescence (whole plant senescence that results after a single reproductive phase) (Nooden and Leopold, 1988), however, in Arabidopsis, somatic tissue longevity does not seem to influenced by reproductive development (Hensel et al., 1993). Leaf senescence is the least well characterized of all senescence processes. Traditionally, studies of leaf senescence relied on exogenous application of hormones or hormone-like substances. Although these studies have provided information about the effects of various hormones, they have provided little information about the hormonal regulation or mechanism of action.

We intend to use the soybean cotyledon model to examine leaf senescence. In the soybean cotyledon system, the organs being studied remain attached thoughout the senescence process. Detached leaves and leaf disks have been used for the study of leaf senescence (Aharoni and Liberman, 1979). Although these systems allow for precise control of experimental parameters of the tissue being studied, care should be taken when attempting to extrapolate the data obtained from an artificial system back to intact tissues. Because senescence is essentially a process of breakdown and remobilization, disruption of source/ sink relationships has been shown to disrupt the normal developmental profile 
of senescence and therefore may change patterns of gene expression (Crafts-Brandner and Egli, 1987).

Soybean Cotyledons as a Model System for Investigations of Senescence and the Reversal of Senescence

It has been demonstrated that senescence in soybean cotyledons is reversible up to a critical point by epicotyl removal (Krul, 1974). This "point of no return" (PONR) is defined as the latest developmental stage at which decapitation results in $100 \%$ regeneration of cotyledons (14 days). Cotyledons that regenerate are termed rejuvenated. Decapitation later than the PONR (i.e., 18, 19 days) results in a lower frequency of cotyledon survival. Rejuvenated cotyledons restore DNA, total nucleic acid, and soluble protein to 5 day levels after losses of $25 \%, 90 \%$, and $80 \%$, respectively. Epicotyl removal results in a burst of nucleic acid synthesis, followed by synthesis of chlorophyll and protein.

Evidence exists that senescence and rejuvenation (the reversal of senescence) are associated with changes in gene expression and several unique mRNA transcripts have been observed (Benhard and Matile, 1994; Lohman, et. al., 1994; Skadsen and Cherry, 1983; Smart, et. al., 1995), although these products have not been fully characterized. The nature of the signals and mechanism by which they modulate these changes are largely unknown.

The soybean cotyledon system should prove to be a valuable tool for investigations of gene expression and regulation during senescence. The reversibility of this process offers a unique opportunity for our investigations in that many genes that appear to be upregulated during senescence should be down-regulated during rejuvenation. In addition, soybean cotyledons are excellent tissues for senescence studies because they senesce within 24 days of planting (Pozsar, 1980). This eliminates the need for the more 
conventional practice of detachment, which is also used to induce senescence (Theologis, 1992) but may induce non-senscence processes such as a wound response.

\section{Rationale and Significance}

Senescence represents a unique phase of plant development eventually leading to death of the plant. Currently, the regulatory mechanisms that facilitate entry into this process are unknown. A better understanding of senescence should provide workers with the information necessary to manipulate this process to avoid current problems with postharvest and post-production losses as well as to improve crop yields. The physiological changes that occur during whole plant and cellular senescence have been well characterized (Nooden, 1988), but only recently has information become available concerning the molecular changes associated with senescing fruit, flower petals, and leaves (Christofferson, et al., 1984; Davies and Grierson, 1989; Holdsworth, et al., 1987a; Holdsworth, et al., 1987b; Lawton, et al., 1989; Meyer, et al., 1991; Petermann and Siedow, 1985; Raghothama, et al., 1991; Sato and Theologis, 1992; Van Der Straeten, et al., 1990; Wang and Woodson, 1991). Genes that exhibit up-regulation during senescence have been isolated and characterized (Davies and Grierson, 1989; Holdsworth, et al., 1987a; Holdsworth, et al., 1987b; Lawton, et al., 1989; Petermann and Siedow, 1985; Sato and Theologis, 1992; Van Der Straeten, et al., 1990; Wang and Woodson, 1991), and all evidence implicates hormonal regulation of these genes. The process of leaf senescence is not well characterized at the molecular level. We believe that the soybean cotyledon system can be exploited to achieve a better understanding of the genetic control over this unique developmental stage. In addition, this system can be used to investigate the process of rejuvenation, or reversal of senescence, which cannot be addressed in other model systems. Experiments have been designed to isolate specific clones that are upregulated during both senescence and rejuvenation. We feel that these clones will 
ultimately be useful in identifying and characterizing the regulatory mechanisms that induces this gene expression though the analysis of the promotor regions of genomic copies of the genes.

To this end, Northern blots have been used to monitor mRNA fluctuations during various stages of senescence and rejuvenation. A collection of both homologous and heterologous clones that are known or suspected to be involved in the two developmental phases has been amassed and has been used as gene-specific probes. These experiments have resulted in developmental profiles of expression of particular genes during senescence and rejuvenation in the soybean cotyledon system. This data has provided a detailed characterization of our system and in turn has validated it as a unique model system for the study of leaf senescence. A cDNA clone, pSIC3e, homologous to the Arabidopsis thaliana Sag2 cysteine protease, has been cloned from senescing soybean cotyledons and initially characterized. A detailed analysis of the promoter region of this clone and a comparison to other senescence induced gene regulatory regions should provide insight into the regulatory sequences that control the senescence process.

Additional experiments to recover other gene clones that are up-regulated during senescence and rejuvenation have been attempted. cDNA libraries generated from presenescent, senescent, and rejuvenated cotyledon mRNA populations and a PCR-based subtractive screen has been employed to isolate differentially expressed genes during senescence and rejuvenation. 


\section{REFERENCES}

Aharoni N, Liberman M (1979) Patterns of ethylene production in senescing leaves. Plant Physiology 64: 796-800.

Aharoni N, Liberman M (1979) Ethylene as a regulator of senescence in tobacco leaf disks. Plant Physiology 64: 801-804.

Bate NJ, Straus NA, Thompson JE (1990) Expression of chloroplast photosynthesis genes during leaf senescence. Physiologia Plantarum 80: 217-225.

Bernhard WR, Matile P (1994) Differential expression of glutamine synthetase genes during the senescence of Arabidopsis thaliana rosette leaves. Plant Science 98: 714

Bonner J, Varner JE (1976) Plant Biochemistry, 3rd ed. Academic Press Inc. New York pg.727.

Borochov A, Woodson, WR (1989) Physiology and biochemistry of flower petal senescence. Horticultural. Review 11: 15-43.

Brady CJ (1987) Fruit ripening. Annual Review Plant Physiology 38:155-178.

Brady CJ (1988) Nucleic acid and protein synthesis. In Nooden LD, Leopold AC, eds, Senescence and ageing in plants Academic Press, San Diego, pp 147-181. 
Burg S P (1962) The physiology of ethylene formation. Annual Review Plant Physiology 13: 265-302.

Carr DJ, Burrows WJ (1966) Evidence of the presence in xylem sap of substances with kinetin-like activity. Life Sciences 5: 2061-2077.

Christofferson RE, Warm E, Laties GG (1982) Gene expression during fruit ripening in avocado. Planta 155:52-57.

Chibnall AC (1954) Protein metabolism in rooted runner bean leaves (1954) New Phytologist 53: 31-37.

Christofferson RE, Tucker ML, Laties GG (1984) Cellulase gene expression in ripening avocado fruit: The accumulation of cellulase mRNA and protein as demonstrated by cDNA hybridization and immuno-detection. Plant Molecular Biology 3:385-391.

Crafts-Brandner S.J., Egli D.B. (1987) Sink removal and leaf senescence in soybean. Plant Physiology 85: 662-666.

Cremer F, Dommes J, Van de Walle C, Bernier G (1990) Diurnal rhythmicity in the pattern of mRNAs in the leaves of Sinapis Alba. Plant Physiology 94: 1590-1597.

Davies KM, Grierson D (1989) Identification of cDNA clones for tomato (Lycopersicon esculentum Mill.) mRNAs that accumulate during fruit ripening and leaf senescence in response to ethylene. Planta 179: 73-80. 
DellaPenna D, Alexander DC, Bennett AB (1986) Molecular cloning of tomato fruit polygalacturonase: Analysis of polygalacturonase mRNA levels during ripening. Proceedings of the National. Academy of Sciences, USA $83: 6420-6424$.

Hensel LL, Grbic V, Baumgarten DA, Bleecker AB (1993) Developmental and agerelated processes that influence the longevity and senscence of photosynthetic tissue in Arabidopsis. The Plant Cell 5: 553-564.

Holdsworth MJ, Bird CR, Ray J, Schuch W, Grierson D (1987) Structure and expression of an ethylene-related mRNA from tomato. Nucleic Acids Research 15: $731-739$.

Holdsworth MJ, Schuch W, Grierson D (1987) Nucleotide sequence of an ethylenerelated gene from tomato. Nucleic Acids Research 15: 10600.

Klee HJ, Romano CP (1994) The roles of phytohormones in development as studied in transgenic plants. Critical Reviews in Plant Science 13(4):31 1-324

Kende H (1971) The cytokinins International Review of Cytology 31:301-338.

Kende H (1965) Kinetin-like factors in root exudates of sunflower. Proceedings of the National. Academy of Sciences, USA 53: 1302-1307.

Krul WR (1974) Nucleic acid and protein metabolism of senescing and regenerating soybean cotyledons. Plant Physiology 54: 36-40. 
Lawton KA, Huang B, Goldsbrough PB, Woodson WR (1989) Molecular cloning and characterization of senescence-related gene expression from carnation flower petals. Plant Physiology 90: 690-696.

Lohman KN, Gan S, Manorama C, Amasino J, Amasino RM (1994) Molecular analysis of natural leaf senescence in Arabidopsis. Physiologia Plantarum 92: 322-328

Marek LF, Stewart CR (1992) Photosynthesis and photorespiration in presenescent, senescent, and rejuvenated soybean cotyledons. Plant Physiology 98: 694-699.

Meyer RCJ, Goldsbrough PB, Woodson WR (1991) An ethylene-responsive flower senescence-related gene from carnation encodes a protein homologous to glutathione s-transferases. Plant Molecular Biology 17: 277-281.

Nooden LD, Leopold AC (eds) (1988) Senescence And Aging In Plants. Academic Press, NY.

Nooden LD (1988) The Phenomena of Senecence and Ageing. In Nooden L.D., Leopold A.C., eds, Senescence and Ageing in Plants. Academic Press, San Diego, pp330-368.

Nooden, LD (1988) The phenomena of senescence and ageing. In Nooden LD, Leopold AC, eds, Senecence and Ageing in Plants. Academic Press, San Deigo, pp2-51.

Peterman TK, Siedow JN (1985) Behavior of lipoxygenase during establishment, senescence, and rejuvenation of soybean cotyledons. Plant Physiology 78: 690695. 
Pozsar BI (1980) Peak levels of endogenous cytokinins after decapitation in leaves of leguminous plants: Increase of protein and chlorophyll contents and photosynthetic ${ }^{14} \mathrm{CO}_{2}$ fixation. Acta Agronomica Academiae Scientiarium, Hungary 29: 47-49.

Raghothama KG, Lawton KA, Goldsbrough PB, Woodson WR (1991) Characterization of an ethylene-regulated flower senescence-related gene from carnation. Plant Molecular Biology 17: 61-71.

Rapp JC, Mullet JE (1991) Chloroplast transcription is required to express the nuclear genes $r b c S$ and cab. Plastid DNA copy number is regulated independently. Plant Molecular Biology 17: 813-823.

Rundle SJ, Zielinski RE (1991) Organization and expression of two tandamly oriented genes encoding ribulose-1,5-bisphosphate carboxylase/oxygenase activase in barley. Journal of Biological Chemistry 266: 4677-4685.

Sabater B, Vera A, Tomas R, Martin M,(1989) Nutrient remobilization, nitrogen metabolism, and chloroplast gene expression in senescent leaves. In Rodriguez $\mathbf{R}$, Sanchez Tames R, Durzan DJ eds, Plant Ageing: Basic and Applied Approaches, Ed Series A Vol 186. Plenum Press, NY, Ny, pp 225-230.

Sambrook J, Fritsch EF, Maniatis T (eds) (1989) Molecular Cloning: A Laboratory Manual, Ed2 Vol1-3. Cold Spring Harbor Laboratory Press. 
Sato T, Theologis A (1989) Cloning the mRNA encoding 1-aminocyclopropane-1caboxylate synthase, the key enzyme for ethylene biosysnthesis in plants.

Proceedings of the National. Academy of Sciences, USA 86: 6621-6625.

Short JM, Fernandez JM, Sorge JA, Huse WD (1988) Lambda ZAP: A bacteriophage lambda expression vector with in vivo excision properties. Nucleic Acids Research 16: $861-868$.

Skadsen RW, Cherry JH (1983) Quantitative changes in In vitro and In vivo protein synthesis in aging and rejuvenated soybean cotyledons. Plant Physiology 71: 861868.

Slater A, Maunders MJ, Edwards K, Schuch W, Greirson D (1985) Isolation and characterisation of $\mathrm{CDNA}$ clones for tomato polygalacturonase and other ripeningrelated proteins. Plant Molecular Biology 5:137-147.

Smart CM, (1994) Gene expression during leaf senescence. New Phytologist 126: 419448

Smart CM, Hosken SE, Thomas H, Greaves JA, Blair BG, Schuch W (1995) The timing of maize leaf senescence and characterization of senescnce-related cDNAs.

Physiologia Plantarum 93: 673-682

Start WG, Ma Y, Pollacco JC, Hildebrand DF, Freyer GA, Altschuler M (1986) Two soybean lipoxygenase nulls accumulate reduced levels of lipoxygenase transcripts. Plant Molecular Biology 7: 11-23. 
Short K, Torrey JG (1972) Cytokinins in seedling roots of pea. Plant Physiology 49: 155-162.

Theologis A (1992) One rotten apple spoils the whole bushel: the role of ethylene in fruit ripening. Cell 70: 181-184.

Thimann K.V., (1980) The senescence of leaves. In Thimann K.V., ed, Senescence in plants. CRC Press, Boca Raton, pp 85-116.

Thomson WW, Plat-Aloia KA (1987). Ultrastructure and senescence in plants. In Plant Senecence: Is Biochemistry and Physiology, Thomson WW, Nothnagel EA, Huffaker RC eds (Rockville, MD: American Society of Plant Physiologists), pp. 20-30.

Van Der Straeten D, Van Wiemeersch L, Goodman HM (1990) Cloning and sequence of two different cDNAs encoding 1-aminocyclopropane-1-carboxylate synthase in tomato. Proceedings of the National. Academy of Sciences, USA 87: 4859-4863.

Wang H, Woodson WR (1991) Reversible inhibition of ethylene action and interuption of petal senescence in carnation flowers by norbornadiene. Plant Physiology 89: 434- 438.

Wang H, Woodson WR (1991) A flower senescence-related mRNA from carnation shares sequence similarity with fruit ripening-related mRNAs involved in ethylene biosynthesis. Plant Physiology 96: 495-502. 
Woodson WR, Lawton KA (1988) Ethyene-induced gene expresion in carnation petals. Plant Physiology 87: 498-503.

Yenofsky RL, Fine M, Liu C (1988) Isolation and characterization of a soybean (Glycine max) lipoxygenase-3 gene. Molecular Genetics 211:215-222 
MANUSCRIPT I

DIFFERENTIAL GENE EXPRESSION DURING SENESCENCE AND THE REVERSAL OF SENESCENCE IN SOYBEAN COTYLEDONS 


\section{ABSTRACT}

Senescence represents the final developmental stage of a plant, tissue, organ or cell. This endogenously controlled degenerative process is characterized by an increase in hydrolytic enzyme activity, break down and remobilization of macromolecular structures, and loss of homeostasis. Soybean cotyledons usually proceed through senescence and abscission within 16-20 days after germination. Senescence can be arrested and reversed by removal of the apical meristem resulting in a regreening or rejuvenation of the cotyledons. The latest point after which decapitation results in rejuvenation of the cotyledons is defined as "the point of no return" (PONR) and occurs approximately 14 days after germination under defined growth conditions. Soybean cotyledons exhibit changes in gene expression during the process of senescence and rejuvenation. A collection of cloned genes that are known or suspected to be involved in senescence or rejuvenation has been amassed from a variety of plants including Arabidopsis, avocado, barley, maize, soybean, and tomato. Clones from this collection have been used as gene specific probes on Northern blots to determine their patterns of expression during the processes of senescence and rejuvenation. Differential gene expression was observed for several of the clones that were analyzed. The Arabidopsis thaliana cysteine protease (Sag2), a carnation ACC synthase (CARACC3), a soybean rubisco carboxylase-oxygenase large subunit (rbcL), and two soybean vegetative storage proteins (pVSP25, pVSP27) all showed strong differential expression in the soybean cotyledon system. Sag2 showed a strong increase in expression up to the PONR, a decrease to presenescent levels on day $14+2$, and increase to senescent levels on day $14+6$. CARACC 3 showed at least five distinct bands that increased to the PONR and decreased to pre-senescent levels on $14+6$. rbcL showed a strong decrease in expression up to PONR and an increase to presenescent on 14+6. pVSP 25 and pVSP 27 both showed a strong decrease to the 8 days, a very strong increase on day 12 , followed by a decrease on PONR, and another increase on day 
14+6. These clones will be valuable in the identification of homologous clones that will be used to study their regulation. 


\section{INTRODUCTION}

Plant leaf senescence involves a series of biochemical and physiological changes that comprise the final stage of development from the mature fully expanded state until death (Smart, et al. 1995). It is a process by which proteins, nucleic acids, and membranes are broken down and the resultant metabolites exported to the developing seeds, storage tissues or other non-senescing tissues. Visible signs of leaf senescence include a preferential degradation of chlorophyll compared to other pigments, which results in a yellowing of the leaf tissue (Matile et al. 1989). During leaf senescence, the photosynthetic apparatus is dismantled and the nutrients are exported to other tissues. Leaf senescence can be induced by a variety of factors, including extremes in temperature, mineral deficiencies, drought, pathogen attack, and shading (Nooden and Leopold, 1988).

Molecular studies indicate that leaf senescence is associated with changes in gene expression (Bate, et al, 1990; Davies and Grierson, 1989; Lawton et al. 1989; Lohman et al. 1994; Mayer et al. 1991; Sabater et al. 1989; Woodson, 1987; Woodson, 1988). Experimental evidence indicates that subsets of genes are up-regulated while others appear to be down-regulated (Woodson, 1987; Davies and Grierson, 1989). mRNAs for glutathione s-transferase, ACC synthase, cellulase, lipoxygenase, and polygalacturonase have been shown to increase, whereas mRNA for ribulose-1,5-bisphosphate carboxylase/oxygenase activase has been shown to decrease during senescence and/or ripening (Christofferson, et. al. 1984; DellaPenna, et. al. 1986; Meyer, et.al. 1991; Park, et. al. 1992; Rundle and Zielinski, 1991). Genes that show differential patterns of expression during leaf or petal senescence have been cloned from a variety of species including maize, Brassica, Arabidopsis, soybean, and carnation (Bernhard and Matile, 1994; Smart et al. 1995; Lohman et al. 1994; Wang and Woodson, 1991)

It has been shown that senescence in soybean cotyledons is reversible, up to a critical point, by epicotyl removal (Krul, 1974). This "point of no return" (PONR) is 
defined as the latest developmental stage at which decapitation results in $100 \%$ regeneration (regreening) of cotyledons (14 days). Cotyledons that regenerate are termed "rejuvenated". Decapitation later than the PONR (i.e., 18, 19 days) results in a lower frequency of cotyledon survival. Rejuvenated cotyledons restore DNA, total nucleic acid, and soluble protein to 5 day levels after losses of $25 \%, 90 \%$, and $80 \%$, respectively (Krul, 1974). Epicotyl removal results in a burst of nucleic acid synthesis, followed by synthesis of chlorophyll and protein.

Soybean cotyledons are well suited for the molecular genetic study of senescence. Relatively large quantities of tissue from all developmental stages can be grown and harvested in 20 days, which makes correlative physiological and biochemical studies possible that are not feasible with other model systems such as Arabidopsis. Because the plants are not fully developed and are not large, only a small growth chamber is needed to carry out an experiment. In addition, the tissue being analyzed remains attached to the plant so natural source/sink relationships remain undisturbed during the senescence process. Finally, the reversal of senescence (i.e. rejuvenation) can be analyzed, which is not possible in other model systems.

Although much information is known about gross changes in nucleic acids, proteins, and gene expression during senescence, relatively little is known about the molecular mechanisms that trigger the senescence syndrome or how it is regulated. Furthermore, virtually no molecular information (either gross or specific changes) is available for rejuvenated tissues. We investigated specific changes in gene expression during senescence and rejuvenation in soybean cotyledons as a first step towards gleaning more detailed information about the molecular events that catalyze these important developmental phases. These studies have resulted in developmental profiles of expression for specific genes during senescence and rejuvenation. These profiles will be useful for determining precise stages of senescence and rejuvenation by providing investigators with genes that can be used as molecular tags. In addition, these genes are candidates for future 
investigations of regulatory regions (e.g., promotor regions and consensus sequences) that may be important for recognition by specific endogenous signals that induce the initial events of senescence and rejuvenation. 


\section{MATERIALS AND METHODS}

Plant materials Soybean plants [Glycine max (L.) Merr; cv. Bass] were maintained in a growth chamber set with a 16-h photoperiod under a light bank consisting of cool white $(80 \%)$ and incandescent $(20 \%)$ bulbs and a $26 / 20^{\circ} \mathrm{C}$ day/night temperature regime. Plants were fertilized on day 0 (the day the seeds were sown) with $27 \mathrm{mg} /$ pot of Peter's 20-2020. Three seeds $(0.19-0.22 \mathrm{~g}$ fresh weight) were planted per 3 inch plastic pot in the promix bx soil formulation. Following emergence, the seedlings were thinned to two uniform plants per pot. Plants were sub-irrigated twice daily with distilled water. All plants were decapitated by removal of the epicotyl 14 days after sowing. Regreened cotyledons from these plants are termed "rejuvenated". Cotyledons were harvested from plants after 5 days, 8 days, 12 days, and 14 days post planting, and $14+2$ days, $14+4$ days, and $14+6$ days post decapitation. The cotyledons were harvested into liquid nitrogen and RNA was extracted immediately.

The point of no return (PONR) was determined experimentally for Glycine max (L.) Merr; cv. Bass under the defined growth conditions. Thirty seeds were sown for each decapitation study, and plants were decapitated on $12,13,14,15,16,17$, and 18 days after sowing. The latest point at which decapitation resulted in $100 \%$ rejuvenation of soybean cotyledons (i.e., the PONR) was on day 14.

Extraction and Purification of RNA- Total soybean cotyledon RNA was extracted from 5 day, 8 day, 12 day, 14 day, 14+2 day, $14+4$ day, any $14+6$ day cotyledons as described by McCarty (1986). mRNA was isolated using the PolyATtract mRNA Isolation System IV according to the manufacturer's instructions (Promega Corporation, Madison, WI). Total and mRNA samples were re-suspended in diethylpolycarbonate (DEPC) treated water and stored at $-70^{\circ} \mathrm{C}$.

Northern Blot Analysis-Northern analysis (Farrell, 1990) was carried out using $1.5 \%$ garose-formaldehyde gels. Samples were transferred to positively charged nylon 
membranes (GeneScreen Plus, Dupont) by capillary diffusion in 10X SSPE (1.5 M NaCl, $0.1 \mathrm{M} \mathrm{Na}_{2} \mathrm{PO}_{4}, 0.01 \mathrm{M}$ EDTA, $\mathrm{pH}$ 7.4) overnight and then fixed to the membrane using a UV StratalinkerTM (Stratagene Cloning Systems, La Jolla, CA). Prehybridizations and hybridizations were carried out according to the manufacturer's recommendations in a hybridization solution $\left(50 \mu \mathrm{l} / \mathrm{cm}^{2}\right)$ consisting of $5 \mathrm{X} \mathrm{SSPE}, 50 \%$ deionized formamide, $5 \mathrm{X}$ Denhardt's solution, $1 \%$ SDS, and $10 \%$ dextran sulfate without denatured DNA. DNA probes were radiolabeled using either Probe-Eze Random primed DNA labeling kit $\left(5^{\prime} \rightarrow\right.$ 3', Incorporated, Boulder, $\mathrm{CO})(50-200 \mathrm{ng}$ purified insert per reaction) or an Oligolabeling kit (Pharmacia Incorporated, Piscataway, NJ) (30-40 ng purified insert per reaction) and $\alpha-32 \mathrm{PdCTP}(3000 \mu \mathrm{Ci} / \mathrm{mmole})$. DNA probes were denatured by heating at $95^{\circ} \mathrm{C}$ for 10 minutes followed by a quick chill on ice for 10 minutes. Denatured radiolabeled probes were added directly to the hybridization solution. Hybridization proceeded overnight at $42^{\circ} \mathrm{C}$ in a shaking water bath, followed by two washes with $200 \mathrm{ml}$ of $2 \mathrm{X}$ SSPE for 15 minutes at room temperature, two washes with $400 \mathrm{ml} 2 \mathrm{X} \mathrm{SSPE}, 2 \%$ SDS for 45 minutes at $65^{\circ} \mathrm{C}$, and two washes with $0.2 \times \mathrm{SSPE}$ for 30 minutes at room temperature until background was sufficiently reduced. Membranes were exposed to Kodak X-OMAT film (Eastman Kodak, Rochester, NY) at $-70^{\circ} \mathrm{C}$ using intensifying screens when necessary. All blot patterns were repeated using multiple, independently extracted RNA preparations. Rehybridized membranes were stripped according to the manufacturer's recommendations (Gene Screen Plus, NEN Dupont Corporation).

Probe Preparation- Plasmids carrying cloned inserts (Table 1) were transformed into $E$. coli strain XL1-Blue (Stratagene Inc., La Jolla, CA) using a standard heat shock protocol (Sambrook, et al, 1988) or electroporation (Gene Pulser II, Biorad Corporation) into E.coli strain XI1-Blue. Transformed cells were grown in large or small scale and plasmid DNA was purified using standard protocols (Sambrook J, et. al. 1988). CsCl gradients were used to purify plasmid DNA that was prepared on a large scale. Purified plasmid samples were resuspended in sterile distilled water, quantitated on a fluorometer, and 
stored at $-20^{\circ} \mathrm{C}$. Plasmid identity was verified by restriction digest analysis. Plasmid DNA was digested using an appropriate restriction enzyme to release the insert, run on a $1 \%$ TAE-LMP agarose gel and the insert band was excised and purified from the LMP agarose using GELase ${ }^{\mathrm{TM}}$ Agarose Gel-Digestion Preparation (Epicentre Technologies, Madison, WI) according to the manufacturer's recommendations. Purified insert DNAs were resuspended in sterile distilled water, quantitated on a fluorometer, and used as probes for Northern analysis. 
Table 1. Cloned genes that were used as gene-specific probes against Northern blots of total RNA from different developmental stages of soybean cotyledons. "Plasmid" indicates the cloning vector for the insert. "Organism" indicates the type of organism the clone was recovered from. "Source" indicates the original source of the clones. All clones were recovered from cDNA libraries. "Function" is listed if known. "Cross-reacts" indicates whether the clone showed any hybridization when used as a probe against soybean cotyledon Northern blots. "Diff. Expressed" indicates whether the clone showed differential expression when used as a gene specific clone against the soybean cotyledon Northern blots. 


\begin{tabular}{|c|c|c|c|c|c|c|}
\hline Clone & Plasmid & Organism & Source & Function & Cross react & Diff. Express \\
\hline SAM 22 & Bluescript IIKS + & Soybean & Crowell & Stress-induced & Yes & No \\
\hline SAM 46 & Bluescript IIKS + & Soybean & Crowell & FE-SOD & Yes & No \\
\hline pSR5 & pGEM 7Zf(+) & Carnation & Woodson & S.R.- Unknown & No & No \\
\hline pSR8 & pGEM 7Zf(+1 & Carnation & Woodson & Glu-S-transferase & No & No \\
\hline pSR12 & pGEM 7Zf(+) & Carnation & Woodson & S.R.- Unknown & No & No \\
\hline CARACC3 & pGEM 7Zf(+1 & Carnation & Woodson & ACC synthase & Yes & Yes \\
\hline pVSP25 & pUC 18 & Soybean & Staswick & Veg storage protein & Yes & Yes \\
\hline pVSP27 & pUC 18 & Soybean & Staswick & Veg storage protein & Yes & Yes \\
\hline p3H9/3 & pGEM 3 & Soybean & Yenofsky & Lipoxygenase-3 & No & No \\
\hline p3H9 & pBR322 & Soybean & Yenofsky & Lipoxygenase-3 & No & No \\
\hline pCVV4A & pUC 18 & Tomato & VanDer Straeten & ACC synthase & No & No \\
\hline pBSICL1.4 & pBSM13+ & cucumber & Graham & Isocitrate lyase & No & No \\
\hline pBSMS1.9 & pBSM13+ & cucumber & Graham & Malate synthase & No & No \\
\hline RubiscoSS & pUC18 & soybean & Meagher & rbsS & Yes & Yes \\
\hline RubiscoLS & pUC18 & soybean & Mullet & rbsL & Yes & Yes \\
\hline SAG2 & Bluescript IIKS+ & Arabidopsis & Bleecker & Cysteine proteinase & Yes & Yes \\
\hline SAG4 & Bluescript IIKS+ & Arabidopsis & Bleecker & S.R.-Unknown & No & No \\
\hline
\end{tabular}




\section{RESULTS}

Gene expression during senescence and the reversal of senescence in soybean cotyledons

Total RNA was extracted from $5,8,12,14,14+2,14+4$, and $14+6$ day old soybean cotyledons, separated on $1.5 \%$ formaldehyde gels and blotted to positively charged nylon membranes. Sample time points were chosen that represented early, middle, and late stages of both senescent and rejuvenated soybean cotyledons. A collection of previously cloned genes that were known or suspected to be involved in senescence, photosynthesis, or rejuvenation were used as gene specific probes to assay changes in gene expression in the soybean cotyledon system (Table 1). Of the 17 clones used as probes on Northern blots, 6 showed some type of differential gene expression. Three of these clones displayed an expression pattern consistent with our predicted developmental pattern based on the known function of each gene-specific probe (Table 1).

CARACC3, which encodes a carnation ACC synthase, was used as a probe on the Northern blots (Figure 1). At least five bands of varying molecular weight hybridized with this probe and all showed an increase in abundance from 5 to 14 days and a subsequent decrease through $14+6$ days. rbcL served as a control that indicated a increase or decrease in chloroplast populations. rbcL encodes the large subunit of soybean rubisco 1,5 bisphosphate oxygenase, carboxylase. This clone hybridized to two bands (Figure 2). The higher molecular weight band was strongest on 5 day, disappeared completely on 8,12 , and 14 day, then reappeared with increasing intensity in $14+2$ and 14+4 day, and was barely visible in $14+6$ day samples. The smaller band hybridized most strongly on 5 day followed by decreasing intensity through 14 day at which point it was not visible. A reappearance of the band was observed with increasing intensity in $14+2$ and 14+4 day RNA samples followed by a virtual disappearance again in the $14+6$ day sample. Sag2 is a senescence-related clone from Arabidopsis thaliana that encodes a cysteine protease. 
Figure 1. Northern blot of cotyledon total RNA populations from different developmental stages using CARACC3 (ACC synthase from carnation petals) as a gene specific probe. $20 \mu \mathrm{g}$ of total RNA preparations from 5 day (green), 8 day (green), 12 day (senescing), and 14 day (senescing) post germination cotyledons, in addition to 2 day $(14+2), 4$ day (14+4) and 6 day (14+6) post decapitation (rejuvenating) cotyledons were separated on a $1.5 \%$ agarose-formaldehyde gel, transferred to a positively charged nylon membrane and probed. 
$\begin{array}{llllllll}5 & 8 & 12 & 14 & 14+2 & 14+4 & 14+6\end{array}$

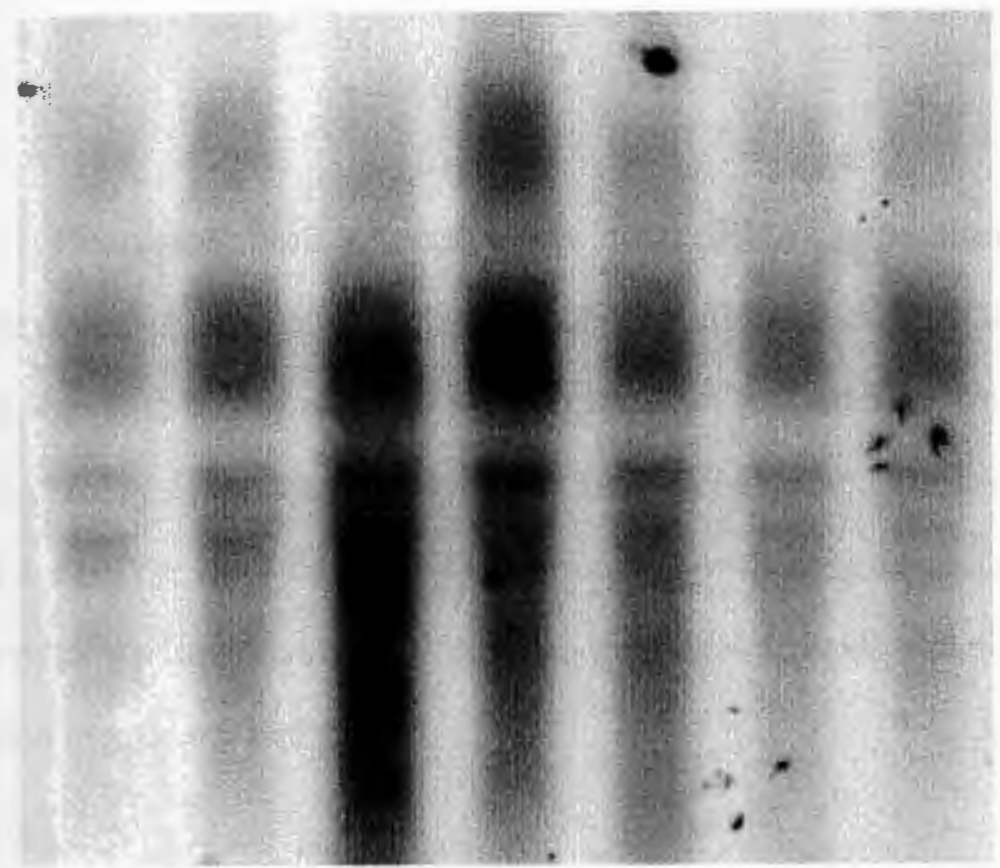


Figure 2. Northern blot of cotyledon total RNA populations from different developmental stages using rbcL (ribulose 1,5-bisphosphate carboxylase,oxygenase from soybean) as a gene specific probe. $20 \mu \mathrm{g}$ of total RNA preparations from 5 day (green), 8 day (green), 12 day (senescing), and 14 day (senescing) post germination cotyledons, in addition to 2 day $(14+2), 4$ day $(14+4)$ and 6 day $(14+6)$ post decapitation (rejuvenating) cotyledons were separated on a $1.5 \%$ agarose-formaldehyde gel, transferred to a positively charged nylon membrane and probed. 
$\begin{array}{llllllll}5 & 8 & 12 & 14 & 14+2 & 14+4 & 14+6\end{array}$

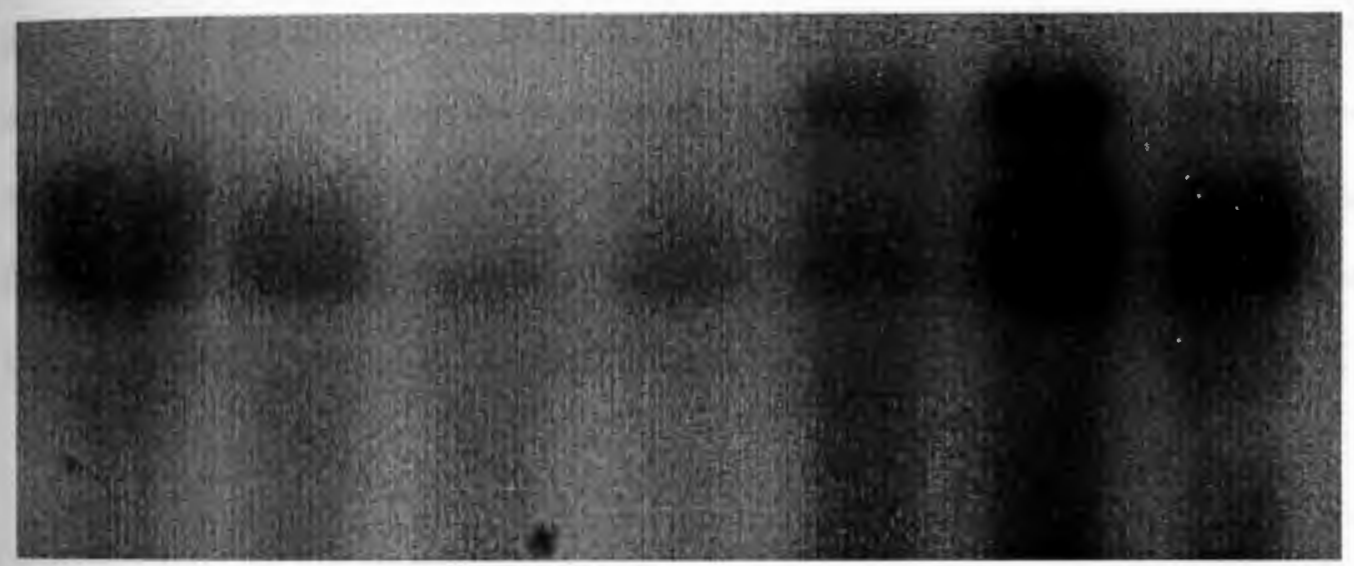


(Hensel et al. 1993). When used as a probe, it hybridized with increasing intensity from 5 to 14 day with approximately equivalent hybridization in 12 and 14 day samples hybridization levels decreased to 5 day levels in $14+2$ day samples and then increased again in 14+4 and 14+6 day samples (Figure 3). VSP 25 and VSP 27 have been shown to encode vegetative storage proteins (Staswick, 1988). When used as gene-specific probes against Northern blots made from the developing soybean cotyledon, both VSP's were down-regulated in 5-8 day post germinated cotyledons, increased in 12 day cotyledons and decreased again in senescing cotyledons. Upon decapitation they were again upregulated (Figures 4 and 5). Ubiquitin is a protein involved in normal turnover of cellular proteins. When pUBS6, a soybean ubiquitin clone, was used as a gene specific probe against Northern blots made from the developing cotyledon system it hybridized with increasing intensity to a maximum value at 14 days, then decreased to presenescent levels on 14+6 days (Figure 6). pSIC3e and pSIC10c are homologs of Sag2 that were cloned from senescing soybean cotyledons (see Manuscript II). As expected, they both exhibited similar patterns of expression to Sag2 (Figure 7). 
Figure 3. Northern blot of cotyledon total RNA populations from different developmental stages using Sag2 (cysteine protease from Arabidopsis) as a gene specific probe. $20 \mu \mathrm{g}$ of total RNA preparations from 5 day (green), 8 day (green), 12 day (senescing), and 14 day (senescing) post germination cotyledons, in addition to 2 day (14+2), 4 day (14+4) and 6 day (14+6) post decapitation (rejuvenating) cotyledons were separated on $1.5 \%$ agarose-formaldehyde gel, transferred to a positively charged nylon membrane and probed. 


\section{$\begin{array}{lllllll}5 & 8 & 12 & 14 & 14+2 & 14+4 & 14+6\end{array}$}


Figure 4. Northern blot of cotyledon total RNA populations from different developmental stages using pVSP25 (vegetative storage protein from soybean) as a gene specific probe. $20 \mu \mathrm{g}$ of total RNA preparations from 5 day (green), 8 day (green), 12 day (senescing), and 14 day (senescing) post germination cotyledons, in addition to 2 day $(14+2), 4$ day $(14+4)$ and 6 day $(14+6)$ post decapitation (rejuvenating) cotyledons were separated on a $1.5 \%$ agarose-formaldehyde gel, transferred to a positively charged nylon membrane and probed. 
$\begin{array}{lllllll}5 & 8 & 12 & 14 & 14+2 & 14+4 & 14+6\end{array}$ 
Figure 5. Northern blot of cotyledon total RNA populations from different developmental stages using pVSP27 (vegetative storage protein from soybean) as a gene specific probe. $20 \mu \mathrm{g}$ of total RNA preparations from 5 day (green), 8 day (green), 12 day (senescing), and 14 day (senescing) post germination cotyledons, in addition to 2 day $(14+2), 4$ day $(14+4)$ and 6 day $(14+6)$ post decapitation (rejuvenating) cotyledons were separated on a $1.5 \%$ agarose-formaldehyde gel, transferred to a positively charged nylon membrane and probed. 
5

8

12

14

$14+2$

$14+4$

$14+6$ 
Figure 6. Northern blot of cotyledon total RNA populations from different developmental stages using pUBS6 (ubiquitin from soybean) as a gene specific probe. 20 $\mu \mathrm{g}$ of total RNA preparations from 5 day (green), 8 day (green), 12 day (senescing), and 14 day (senescing) post germination cotyledons, in addition to 2 day (14+2), 4 day (14+4) and 6 day $(14+6)$ post decapitation (rejuvenating) cotyledons were separated on a $1.5 \%$ agarose-formaldehyde gel, transferred to a positively charged nylon membrane and probed. 
$\begin{array}{lllllll}5 & 8 & 12 & 14 & 14+2 & 14+4 & 14+6\end{array}$ 
Figure 7a, b Northern blot of cotyledon total RNA populations from different developmental stages using pSIC3e (a) and pSIC10c (b) homologous clones of Sag2 from soybean cotyledons, as gene specific probes. $20 \mu \mathrm{g}$ of total RNA preparations from 5 day (green), 8 day (green), 12 day (senescing), and 14 day (senescing) post germination cotyledons, in addition to 2 day $(14+2), 4$ day $(14+4)$ and 6 day $(14+6)$ post decapitation (rejuvenating) cotyledons were separated on a $1.5 \%$ agarose-formaldehyde gel, transferred to a positively charged nylon membrane and probed. 
$\begin{array}{lllllll}5 & 8 & 12 & 14 & 14+2 & 14+4 & 14+6\end{array}$
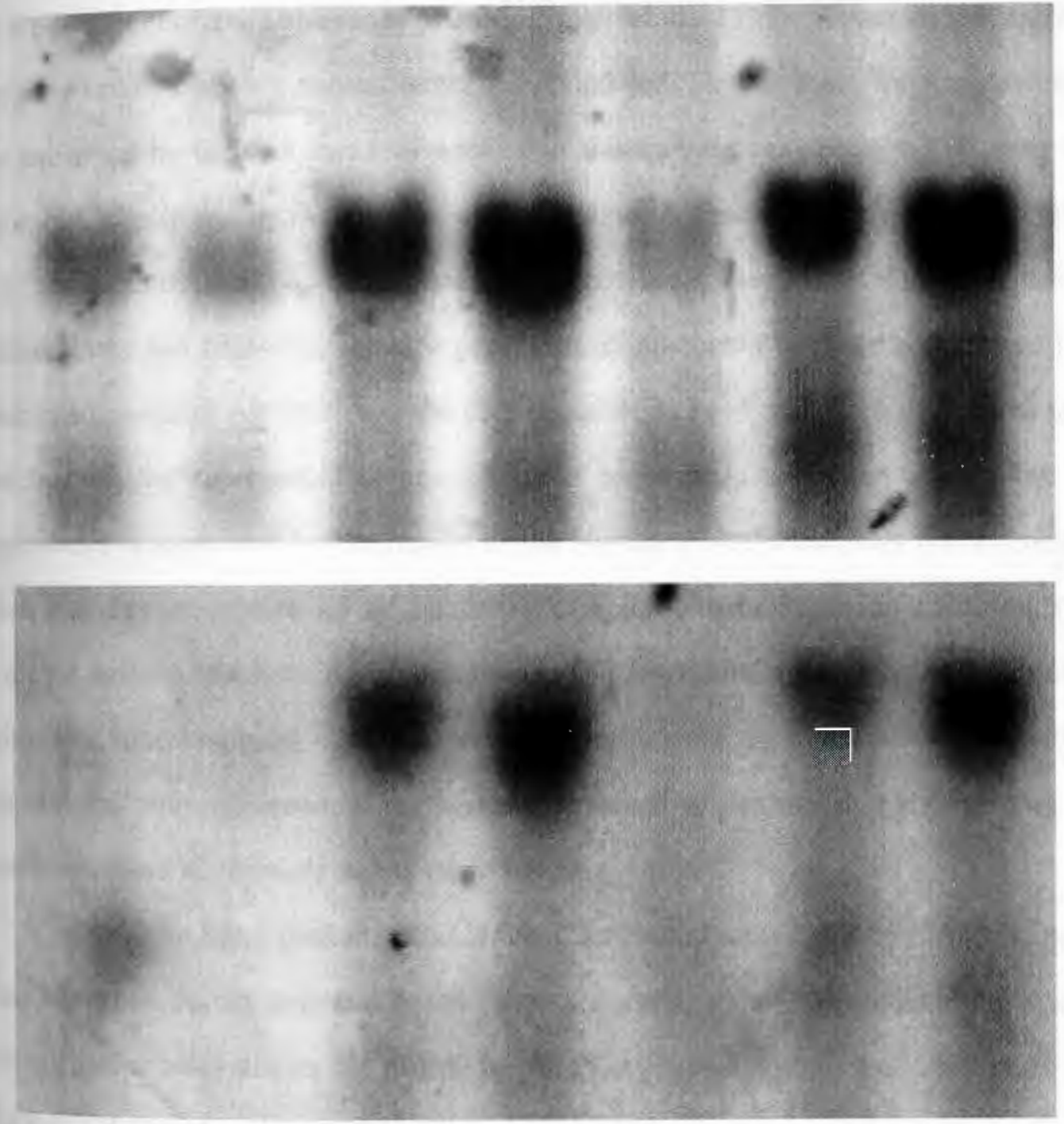


\section{DISCUSSION}

When Northern blots were probed with Sag2 the resulting patterns of gene expression were consistent with our predicted pattern for a cysteine protease. As expected, the level of protease mRNA should increase during senescence because as the degradation of proteins and remobilization of the resultant nutrients to other plant organs is a major part of the senescence process (Smart et al., 1995). However, during the later stages of rejuvenation a second increase in Sag2 mRNA was seen. This observation may be explained by the fact that rejuvenation in the soybean cotyledon system was defined morphologically and by the color of the cotyledons. It seems reasonable that proteins that are not essential to the metabolism of the cotyledon would be degraded before the chloroplasts and associated energy generating components because senescence requires energy to proceed. Alternatively, the cotyledons from $14+4$ and $14+6$ day stages could be far beyond the rejuvenated stage and could be actively senescing again. The former hypothesis is supported by the results of the Northern blot which was probed with rbcL. $r b c L$ encodes the rubisco 1,5 bis-phosphate oxygenase/carboxylase large subunit, which is a major enzyme involved in photosynthesis. The pattern of expression rbcL is consistent with the morphological observations that were used to discern various stages of senescence and rejuvenation in that we observed a decline in $r b c L$ mRNA during senescence and an increase during rejuvenation.

Northern blots probed with CARACC 3 resulted in at least five hybridizing bands that increased during senescence and decreased during rejuvenation. The major pathway for ethylene biosynthesis in plants is the Yang cycle (Yang and Hoffman, 1984). CARACC3 encodes a carnation ACC synthase. This enzyme catalyzes the rate limiting step in ethylene biosynthesis and is known to have multiple isoforms (Wang and Woodson, 1991). Ethylene is a major hormone involved in fruit ripening (Theologis, 1992). Fruit ripening and senescence are closely related processes and some genes have been found 
that show sequence similarity (Wang and Woodson, 1991); therefore, it is not unexpected that ACC synthase appears to be differentially regulated during senescence and rejuvenation in the soybean cotyledon. The appearance of multiple bands suggests that ACC synthase is an important and highly regulated enzyme during senescence and rejuvenation in soybean cotyledons, and therefore ethylene may play a key role in the regulation of these processes. Experiments to discern the role of ethylene on senescence and rejuvenation in soybean cotyledons could be carried out using ethylene biosynthesis mutants. Northern blots could be used to evaluate differential gene expression of ACC synthase and other key enzymes involved in ethylene biosynthesis.

The VSP (vegetative storage proteins) proteins have been the subject of much investigation (Staswick, 1988; Staswick, 1989; Staswick, 1990). These vegetative storage proteins appear to be important as temporary storage molecules for nitrogen (amino acids) in vegetative tissues (leaves). They are regulated by multiple stimuli (Staswick, 1989; Staswick, 1990), but most notable is their up-regulation in depodded soybean plants which exhibit delayed senescence. Northern blots probed with pVSP 25 and pVSP 27 showed a transient increase just prior to senescence that was initially puzzling. After repeated analysis of several Northern blots the possibility of unequal loading was eliminated. Work with soybean leaves has shown similar transient up-regulation just prior to senescence (Staswick, 1988). This unique pattern of expression suggests a high level of regulation in the cotyledons of soybean.

pUBS6 is a soybean ubiquitin. Ubiquitin is involved in protein turnover. When pUBS6 was used as a gene specific probe against the soybean cotyledon system we observed an increase in intensity up to 14 days, followed by a return to presenescent levels on $14+6$ days (Figure 6). These observations agree with our predicted pattern of expression because senescence is a process that involves turnover of nutrients and subsequent export to other organs and/or tissues. 
pSIC3e and pSIC10c are homologs clones of Sag2 that were isolated from soybean (See Manuscript II). As expected they both exhibit similar patterns of expression to Sag2 (Figure 7).

All total RNA samples were loaded on mass basis. We attempted to normalize these blot by probing with our gene of interest and ubiquitin. Ubiquitin was chosen because it expressed in during most stages of development at a constant level and is frequently used to normalize Northern blots. We saw an increase in expression of ubiquitin during senescence when used as a probe against our Northern blots. This result can be explained by the fact that ubiquitin is involved in protein turnover, and increases in protein turnover occur in senescing tissues as nutrients are prepared for export to other cells, tissues, and/or organs. One method to address the problem of unequal loading, is to normalize against rRNA. This experiments are currently in progress (results not shown), and preliminary data confirms our original conclusions. 


\section{LITERATURE CITED}

Bate NJ, Straus NA, Thompson JE (1990) Expression of chloroplast photosynthesis genes during leaf senescence. Physiologia Plantarum 80: 217-225.

Christofferson RE, Tucker ML, Laties GG (1984) Cellulase gene expression in ripening avocado fruit: The accumulation of cellulase mRNA and protein as demonstrated by cDNA hybridization and immuno-detection. Plant Molecular Biology 3:385-391.

Bernhard WR, Matile P (1994) Differential expression of glutamine synthetase genes during the senescence of Arabidopsis thaliana rosette leaves. Plant Science 98: $7-14$

Davies KM, Grierson D (1989) Identification of cDNA clones for tomato (Lycopersicon esculentum Mill.) mRNAs that accumulate during fruit ripening and leaf senescence in response to ethylene. Planta 179: 73-80.

DellaPenna D, Alexander DC, Bennett AB (1986) Molecular cloning of tomato fruit polygalacturonase: Analysis of polygalacturonase mRNA levels during ripening. Proceedings of the National Academy of Sciences, USA. $83: 6420-6424$.

Farrell, RE., Jr. Methodologies for RNA characterization II: quantitation by northern blot analysis and the S1 nuclease assay. Clinical Biotechnology 2 (1990): 107-119 
Hensel LL, Grbic V, Baumgarten DA, Bleecker AB (1993) Developmental and agerelated processes that influence the longevity and senscence of photosynthetic tissue in Arabidopsis. The Plant Cell 5: 553-564.

Krul WR (1974) Nucleic acid and protein metabolism of senescing and regenerating soybean cotyledons. Plant Physiology 54: 36-40.

Lawton KA, Huang B, Goldsbrough PB, Woodson WR (1989) Molecular cloning and characterization of senescence-related gene expression from carnation flower petals. Plant Physiology 90: 690-696.

Lohman KN, Gan S, Manorama C, Amasino J, Amasino RM (1994) Molecular analysis of natural leaf senescence in Arabidopsis Physiologia Plantarum 92: 322-328

Meyer RCJ, Goldsbrough PB, Woodson WR (1991) An ethylene-responsive flower senescence-related gene from carnation encodes a protein homologous to glutathione s-transferases. Plant Molecular Biology 17: 277-281.

Nooden LD, Leopold AC (eds) (1988) Senescence And Aging In Plants. Academic Press, NY.

Park KY, Drory A, Woodson WR (1992) Molecular cloning of an 1aminocyclopropane-1-carboxylate synthase from senescing carnation petals. Plant Molecular Biology 18: 377-386. 
Rundle SJ, Zielinski RE (1991) Alterations in barley ribulose-1,5-bisphosphate carboxylase/oxygenase activase gene expression during development and in response to illumination. Journal of Biological Chemistry 266: 14802-14807.

Sabater B, Vera A, Tomas R, Martin M,(1989) Nutrient remobilization, nitrogen metabolism, and chloroplast gene expression in senescent leaves. In Rodriguez R, Sanchez Tames R, Durzan DJ eds, Plant Ageing: Basic and Applied Approaches, Ed Series A Vol 186. Plenum Press, NY, Ny, pp 225-230.

Sambrook J, Fritsch EF, Maniatis T (eds) (1989) Molecular Cloning: A Laboratory Manual, Ed 2 Vol 1-3. Cols Spring Harbor Laboratory Press

Smart CM, Hosken SE, Thomas H, Greaves JA, Blair BG, Schuch W (1995) The timing of maize leaf senescence and characterization of senescnce-related cDNAs. Physiologia Plantarum 93: 673-682

Staswick PE (1988) Soybean vegetative storage protein structure and gene expression. Plant Physiology 87:647-656

Staswick PE (1989) Developmental regulation and the influence of plant sinks on vegetative storage protein gene expression in soybean leaves. Plant Physiology 89: $309-315$

Staswick PE (1990) Novel regulation of vegetative storage protein genes. The Plant Cell 2:1445-1446 
Theologis A (1992) One rotten apple spoils the whole bushel: the role of ethylene in fruit ripening. Cell 70: 181-184.

Wang H, Woodson WR (1991) Reversible inhibition of ethylene action and interuption of petal senescence in carnation flowers by norbornadiene. Plant Physiology 89: 434-438.

Wang H, Woodson WR (1991) A flower senescence-related mRNA from carnation shares sequence similarity with fruit ripening-related mRNAs involved in ethylene biosynthesis. Plant Physiology 96: 495-502.

WoodsonWR (1987) Changes in protein and mRNA populations during senescence of carnation petals. Physiologia Plantarum 71:495-502.

Woodson WR, Lawton KA (1988) Ethyene-induced gene expresion in carnation petals. Plant Physiology 87: 498-503. 
MANUSCRIPT II:

ISOLATION OF A SOYBEAN cDNA CLONE WITH HOMOLOGY TO Sag2, A SENESCENCE-ASSOCIATED GENE FROM ARABIDOPSIS 
Senescence represents the final developmental stage of the plant, tissue, organ or cell. This endogenously controlled degenerative process is characterized by an increase in hydrolytic enzyme activity, break down and remobilization of macromolecular structures, and loss of homeostasis. Soybean cotyledons usually proceed through senescence and abscission within 16-20 days after germination. Senescence can be arrested and reversed by removal of the apical meristem, resulting in a regreening or "rejuvenation" of the cotyledons. The latest point after which decapitation results in rejuvenation of the cotyledons is defined as "the point of no return" (PONR) and occurs approximately 14 days after germination under defined growth conditions. Soybean cotyledons exhibit changes in gene expression during the process of senescence and rejuvenation. A soybean cotyledon cDNA library has been constructed from PONR senescing cotyledons and homologues to the senescenceassociated Arabidopsis Sag2 gene has been cloned. pSIC3e is a $1.4 \mathrm{~kb}$ fragment and pSIC10c is a $1.2 \mathrm{~kb}$ fragment. Both clones contain two PvuII sites. 


\section{INTRODUCTION}

Leaf senescence is an important developmental phase in which cells undergo distinct metabolic and structural changes prior to cell death (Nooden and Leopold, 1988). It is a process by which proteins, nucleic acids, and membranes are broken down and the resultant metabolites shipped to the developing seeds or storage organs. Visible signs of leaf senescence include loss of chlorophyll and a degeneration of the photosynthetic apparatus, which results in a yellowing of the leaf tissue. Leaf senescence can be induced by a variety of factors including extremes in temperature, mineral deficiencies, drought, pathogen attack, and shading (Nooden and Leopold, 1988).

Molecular studies indicate that leaf senescence is associated with changes in gene expression (Lohman et. al., 1994; Woodson, 1988; Bate, et al, 1990; Sabater, et. al., 1989). Experimental evidence indicates that subsets of genes are upregulated while others appear to be down regulated (Woodson, 1987; Davies and Grierson, 1989). mRNAs for glutathione s-transferase, ACC synthase, cellulase, lipoxygenase, and polygalacturonase have been shown to increase, whereas mRNAs for ribulose-1,5-bisphosphate carboxylase/oxygenase activase has been shown to increase during senescence and/or ripening (Christofferson, et. al. 1984; DellaPenna, et. al. 1986; Meyer et.al. 1991; Park, et. al. 1992; Rundle and Zielinski, 1991).

Although much information is known about gross changes in nucleic acids, proteins, and gene expression during senescence, relatively little is known about the molecular mechanisms that trigger the senescence syndrome or how it is regulated. Furthermore, virtually no molecular information (either gross or specific changes) is available for rejuvenated tissues. We investigated specific changes in gene expression during senescence and rejuvenation in soybean cotyledons as a first step towards gleaning more detailed information about the molecular events that catalyze these important developmental phases. We have identified a senescence-associated Arabidopsis Sag2 gene 
that shows differential expression during senescence and rejuvenation in soybean cotyledons and have cloned the soybean homologue. This clone is a candidate for future investigations of important regulatory regions (i.e., consensus sequences) that are involved in the coordination of senescence and rejuvenation. 


\section{MATERIALS AND METHODS}

Plant materials Soybean plants (Glycine max (L.) Merr; cv. Bass) were grown in a growth chamber set with a 16-h photoperiod under a light bank consisting of cool white $(80 \%)$ and incandescent $(20 \%)$ bulbs and a $26 / 20^{\circ} \mathrm{C}$ day/night temperature regime. Plants were fertilized on day 0 (the day the seeds were sown) with $27 \mathrm{mg}$ of Peter's 20-20-20. Three seeds $(0.19-0.22 \mathrm{~g}$ fresh weight) were planted per 3 inch plastic pot in the pro-mix bx soil formulation. Following emergence, the seedlings were thinned to two uniform plants per pot. Plants were sub-irrigated twice daily with distilled water. All plants were decapitated by removal of the epicotyl after 14 days from sowing. Regreened cotyledons from these plants are termed "rejuvenated". Cotyledons were harvested from plants after 5 days, 8 days, 12 days, 14 days post planting, 14+2 days, $14+4$ days, and $14+6$ days post decapitation. The cotyledons were harvested into liquid nitrogen and RNA was extracted immediately. The point of no return (PONR) was determined experimentally for Glycine $\max (\mathrm{L}$.) Merr; cv. Bass under the defined growth conditions. Thirty seeds were sown for each decapitation study, and plants were decapitated on $12,13,14,15,16,17$, and 18 days after sowing. The latest point at which decapitation resulted in $100 \%$ rejuvenation of soybean cotyledons was determined to be the PONR.

Extraction and Purification of RNA- Total soybean cotyledon RNA was extracted from 5 day, 8 day, 12 day, 14 day, 14+2 day, 14+4 day, any 14+6 day cotyledons as described by McCarty (1986). mRNA was isolated using the PolyATtract mRNA Isolation System IV according to the manufacturer's instructions (Promega Corporation, Madison, WI). Total and mRNA samples were re-suspended in diethylpolycabonate (DEPC) treated water and stored at $-70^{\circ} \mathrm{C}$.

Probe Preparation- Plasmids carrying cloned inserts (see fig.1) were transformed into $E$. coli strain XL1-Blue using a standard heat shock protocol (Sambrook J, et. al. 1988) or electroporation (Biorad Corporation) into E.coli strain XL1-Blue. Transformed cells were 
grown large scale and small scale and plasmid DNA was purified using standard protocols (Sambrook J, et. al. 1988). CsCl gradients were used to purify plasmid DNA that was prepared large scale. Purified plasmid samples were re-suspended in sterile distilled water, quantitated on a flourometer, and stored at $-20^{\circ} \mathrm{C}$. Plasmid identity was verified by restriction digest analysis. Plasmid DNA was digested using an appropriate restriction enzyme to release the insert, run on a $1 \%$ TAE-LMP agarose gel and the insert band was excised and purified from the LMP agarose using GELase ${ }^{\text {TM }}$ Agarose Gel-Digestion Preparation (Epicentre Technologies, Madison, WI) according to the manufacturer's recommendations. Purified insert DNAs was resuspended in sterile distilled water, quantitated on a flourometer, and used as probes for Northern analysis.

\section{cDNA library construction}

Poly (A)+ RNA used for construction of cDNA libraries was isolated as described above. RNA isolated from PONR senescing cotyledons was used as starting material to construct a cDNA library using a ZAP-cDNA synthesis kit according to the manufacturers recommendations (Stratagene Incorporated, LaJolla, CA). First strand synthesis was accomplished using oligo (dT)18-Xho I as a primer with M-MuLV reverse transcriptase and a dNTP containing 5 methyl dCTP. The second strand was synthesized using $E$. coli DNA Polymerase I and E. coli RNase H. Double-stranded cDNA was blunted using T4 DNA polymerase and EcoRI adapters were ligated onto blunted cDNA using T4 DNA ligase. Adapter ends were phosphorylated using T4 polynucleotide kinase and the resultant cDNA was digested with XhoI followed by ethanol precipitation. cDNA was ligated into Uni-ZAP XR vector arms using T4 DNA ligase. Recombinant DNA was packaged using a

Gigapack II Gold packaging extract kit (Stratagene Incorporated, LaJolla, CA) and transformed into $E$. coli strain XL1-Blue MR-F' by heat shock. The 14 day cDNA library contained $1.9 \times 10^{6}$ recombinant clones. 


\section{cDNA library screening}

\section{Primary Screen}

For library screening, 60,000 recombinant phage were plated at a density of 10,000/plate and lifted to positively charged nylon filters (Genescreen Plus NEN Research products, Boston, MA). The Sag2 cDNA probe was digested with PstI to release the insert, purified twice, and radiolabeled using an Oligolabeling kit (Pharmacia Incorporated, Piscataway, NJ) (30-40 ng purified insert per reaction) and $\alpha-32 \mathrm{PdCTP}(3000 \mu \mathrm{Ci} / \mathrm{mmole})$. DNA probes were denatured by heating at $95^{\circ} \mathrm{C}$ for 10 minutes followed by a quick chill on ice for 10 minutes. Denatured radiolabeled probes were added directly to the hybridization solution. Hybridizations were carried out for $16-24$ hours at $42^{\circ} \mathrm{C}$. Filters were washed in $2 \mathrm{X} \mathrm{SSC}$ at room temperature for 15 minutes, twice in $0.2 \mathrm{X}$ SSC $+1 \%$ SDS at room temperature for 30 minutes, and twice in $0.1 \mathrm{XSSC}+1 \%$ SDS at room temperature for 15 minutes. Filters were exposed to X-ray film (Eastman Kodak, Rochester, NY) at $-70^{\circ} \mathrm{C}$ using intensifying screens. Filters were aligned to their corresponding developed $\mathrm{X}$-ray films and 30 plaques that showed strong hybridization signals were selected and eluted in $50 \mu \mathrm{l} \mathrm{SM}$ buffer overnight at $4^{\circ} \mathrm{C}$.

\section{Secondary Screen}

Half of the 30 eluted plaque preparations from the primary screen were freeze thawed twice and amplified by PCR in a $50 \mu l$ reaction volumes (1X PCR reaction buffer, $\mathrm{MgCl} 2$ free, $0.2 \mathrm{mM} d N T P, 200 \mathrm{ng}$ T-3 primer, 200ng T-7 primer, 0.2U Taq polymerase (Promega Corporation Madison, WI) using the following cycling parameters: $94^{\circ} \mathrm{C} 1$ minute followed by 30 cycles of $94^{\circ} \mathrm{C}$ for 30 seconds, $58^{\circ} \mathrm{C}$ for 30 seconds, and $72^{\circ} \mathrm{C}$ for 30 seconds, followed by 1 cycle of $72^{\circ} \mathrm{C}$ for 3 minutes. Multiple bands were observed in each sample when a $20 \mu$ aliquot of each reaction was electrophoresed on a $1 \%$ TAE agarose 
gel at 60 volts for 2.5 hours. The resultant gel was agitated in $0.25 \mathrm{~N} \mathrm{HCl}$ for 10 minutes, in $0.4 \mathrm{~N} \mathrm{NaOH} / 0.6 \mathrm{M} \mathrm{NaCl}$ for 30 minutes, and finally in $1.5 \mathrm{M} \mathrm{NaCl} / 0.5 \mathrm{MTris}-\mathrm{HCl} \mathrm{pH}$ 7.5 for 30 minutes, and then transferred to GeneScreen Plus membrane (NEN Research Products, Boston MA) by capillary diffusion in $10 \mathrm{X}$ SSC. The membrane was fixed by UV crosslinking and probed with Sag2 that was purified and radiolabelled as described above. Ten samples containing at least one large molecular weight band that also hybridized strongly were selected for a tertiary screen.

\section{Tertiary Screen}

The second half of the elutions from each of the ten positive sample were plated onto fresh NZY plates at a lower titer and five plaques from each elution for a total of 50 were selected at random and eluted in $50 \mu \mathrm{SM}$ buffer overnight at $4^{\circ} \mathrm{C}$ and PCR amplified as described above. Single bands were observed in most samples when a $20 \mu$ l aliquot of each reaction was electrophoresed on a $1.0 \%$ TAE agarose gel at 60 volts for 2.5 hours. Clones were selected for a quaternary screen based on a comparison of the size of the band on the tertiary screen blot to the size of the putative positive insert on the secondary screen.

\section{Quaternary Screen}

Single putative positive clones were excised and eluted in $50 \mathrm{ul} \mathrm{SM}$ buffer overnight at $4^{\circ} \mathrm{C}$ and PCR amplified as described above. A $20 \mu \mathrm{l}$ aliquot was run an a 1.0\% TAE agarose gel, transferred to membrane and hybridized to Sag2 as described above. Samples that hybridized strongly were selected for confirmation on Northern blots.

\section{Northern Confirmation}

Total RNA from $5,8,12,14,14+2,14+4$, and $14+6$ day old cotyledons was extracted as described above. Northern analysis (Farrell, 1990) was carried out using $1.5 \%$ agarose- 
formaldehyde gels. $20 \mu \mathrm{g}$ of each sample were transferred to positively charged nylon membranes (GeneScreen Plus, Dupont) by passive capillary diffusion in 10X SSPE (1.5 M $\mathrm{NaCl}, 0.1 \mathrm{M} \mathrm{Na}_{2} \mathrm{PO}_{4}, 0.01 \mathrm{M}$ EDTA, $\mathrm{pH}$ 7.4) overnight and then fixed to the membrane using a UV Stratalinker ${ }^{\mathrm{TM}}$ (Stratagene Cloning Systems, La Jolla, CA). Prehybridizations and hybridizations were carried out according to the manufacturer's recommendations in a hybridization solution $\left(50 \mu 1 / \mathrm{cm}^{2}\right)$ consisting of $35 \%$ formamide, $6 \%$ dextran sulfate, $0.5 \%$ SDS, $1 \mathrm{X}$ Denhardt's solution, and $1 \mathrm{M} \mathrm{NaCl}$ without denatured DNA. DNA probes were radiolabeled using either a Probe-Eze Random primed DNA labeling kit (5' $\rightarrow 3^{\prime}$, Incorporated, Boulder, $\mathrm{CO})(50-200 \mathrm{ng}$ purified insert per reaction) or an Oligolabeling kit (Pharmacia Incorporated, Piscataway, NJ) (30-40 ng purified insert per reaction) and $\alpha-32 \mathrm{PdCTP}(3000 \mu \mathrm{Ci} / \mathrm{mmole})$. DNA probes were denatured by heating at $95^{\circ} \mathrm{C}$ for 10 minutes followed by a quick chill on ice for 10 minutes. Denatured radiolabeled probes were added directly to the hybridization solution. Hybridization proceeded overnight at $42^{\circ} \mathrm{C}$ in a shaking water bath, followed by two washes using $200 \mathrm{ml}$ of $2 \mathrm{X}$ SSPE for 15 minutes at room temperature, with two washes of $400 \mathrm{ml}$ of $2 \mathrm{X}$ SSPE, $2 \%$ SDS for 45 minutes at $65^{\circ} \mathrm{C}$, and two washes of $0.2 \times$ SSPE for 30 minutes at room temperature until background was sufficiently reduced. Membranes were exposed to Kodak X-OMAT film (Eastman Kodak, Rochester, NY) at $-70^{\circ} \mathrm{C}$ using intensifying screens when necessary.

\section{Restriction Analysis}

Clones that were confirmed by Northern analysis were initially characterized by restriction analysis. Single enzyme digests were performed with EcoRI, NotI, SmaI, HindIII, ScaI, PvuII, XhoI, and XbaI according to the manufacturer's recommendations (Promega Corporation). Double digests were performed with PvuII/XboI, EcoRI/XhoI, and EcoRI/PvuII according to the manufacturer's recommendation (Promega Corporation). Restriction products were run on a $1.0 \%$ TAE agarose gel, stained with eithidium bromide and visualized on a UV trans illuminator. 


\section{RESULTS}

\section{cDNA screening}

From a total of 100,000 primary screen plaques, thirty showed strong hybridization when probed with Sag2 and were selected for a secondary screen (results not shown). For a secondary screen these plaques were eluted and half of each elution was amplified by PCR and separated on a $1.0 \%$ agarose gel where multiple bands ( 0 to 3 bands) were visible (an average of 1.7 bands per core) (Figures 1a, and 1c). Upon transfer to a positively charged nylon membrane and probing with Sag2, ten of the thirty samples were seen to contain high molecular weight bands that hybridized strongly; these were selected for a tertiary screen (Figures $1 \mathrm{~b}$ and $1 \mathrm{~d}$ ). The ten positive samples from the secondary screen were replated at a low titer and five random isolates were selected from each sample. From a total of fifty plaques that were amplified by PCR, five random isolates from each of the ten samples from the secondary screen, twenty contained single bands that were the same molecular weight as the corresponding bands that hybridized strongly in the secondary screen (Figures $2 \mathrm{a}$ and $2 \mathrm{~b}$ ) and were chosen for a quaternary screen. Eleven of these twenty hybridized strongly to Sag2 (Figures 3a and 3b).

\section{Northern blot analysis}

Two clones, pSIC $3 \mathrm{e}$ and pSIC10c, were selected for confirmation by Northern analysis. Both clones showed similar patterns of expression compared to the original Northern blot probed with Sag2. pSIC3e and pSIC10c were not expressed on day 5, showed a strong increase in expression to a maximum level on day 14 , followed by a dramatic decrease to five day levels on day $14+2$ and another increase to day $14+6$ (Figures $4 a-c$ ). 
Figure 1 (a) $2^{\circ}$ Screen: Agarose gel electrophoresis of PCR amplification products from plaque isolates numbered 1 through 15 from the primary screen. PCR products were separated in a $1.0 \%$ agarose gel, stained with ethidium bromide, and visualized by UV. Marker lane (M) is digested with Hind III $\lambda$ DNA $(0.5 \mu \mathrm{g})$. (b) $2^{\circ}$ Screen: Southern blot of in (a) gel using Sag2 as a probe. 
A

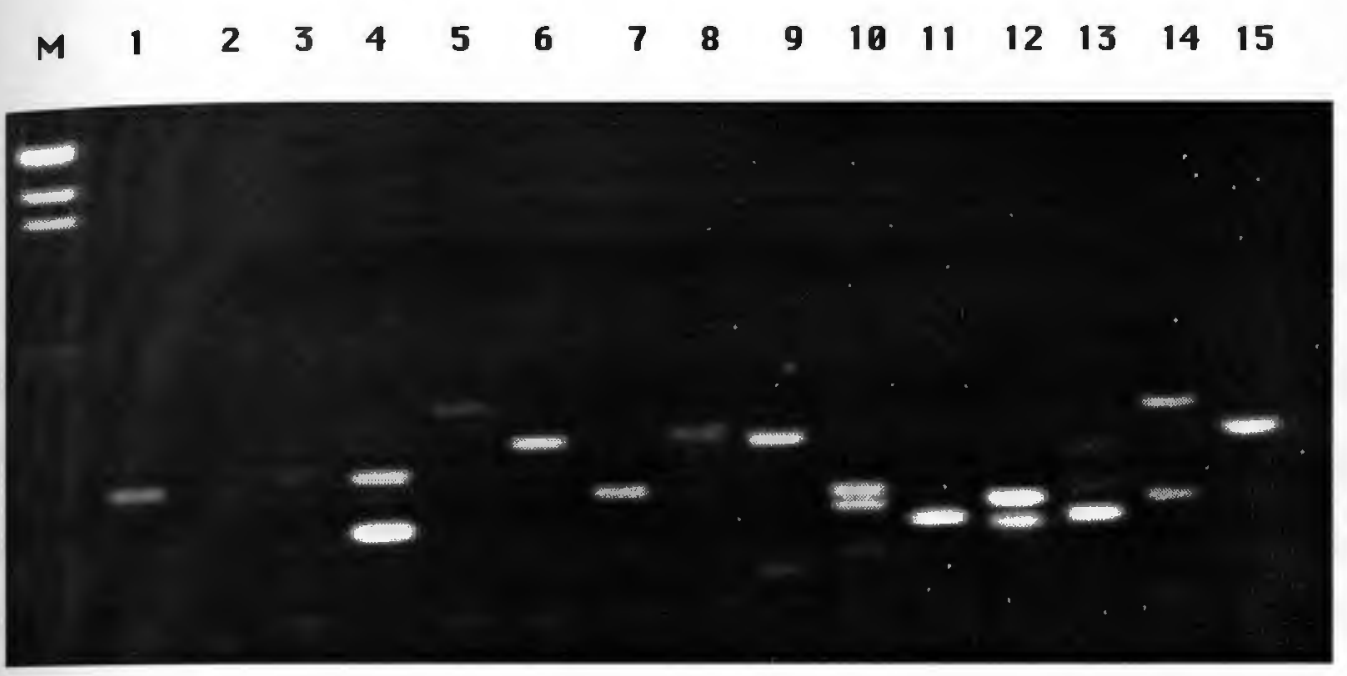

B

$$
\begin{array}{lllllllllllllll}
1 & 2 & 3 & 4 & 5 & 6 & 7 & 8 & 9 & 18 & 11 & 12 & 13 & 14 & 15
\end{array}
$$


Figure 1 (c) $2^{\circ}$ Screen: Agarose gel electrophoresis of PCR amplification products from plaque isolates numbered 16 through 30 from the primary screen. PCR products were separated in a $1.0 \%$ agarose gel, stained with ethidium bromide, and visualized by UV. Marker lane (M) is digested with Hind III $\lambda$ DNA $(0.5 \mu \mathrm{g})$. (d) $2^{\circ}$ Screen: Southern blot in (c) gel using Sag2 as a probe. 
C

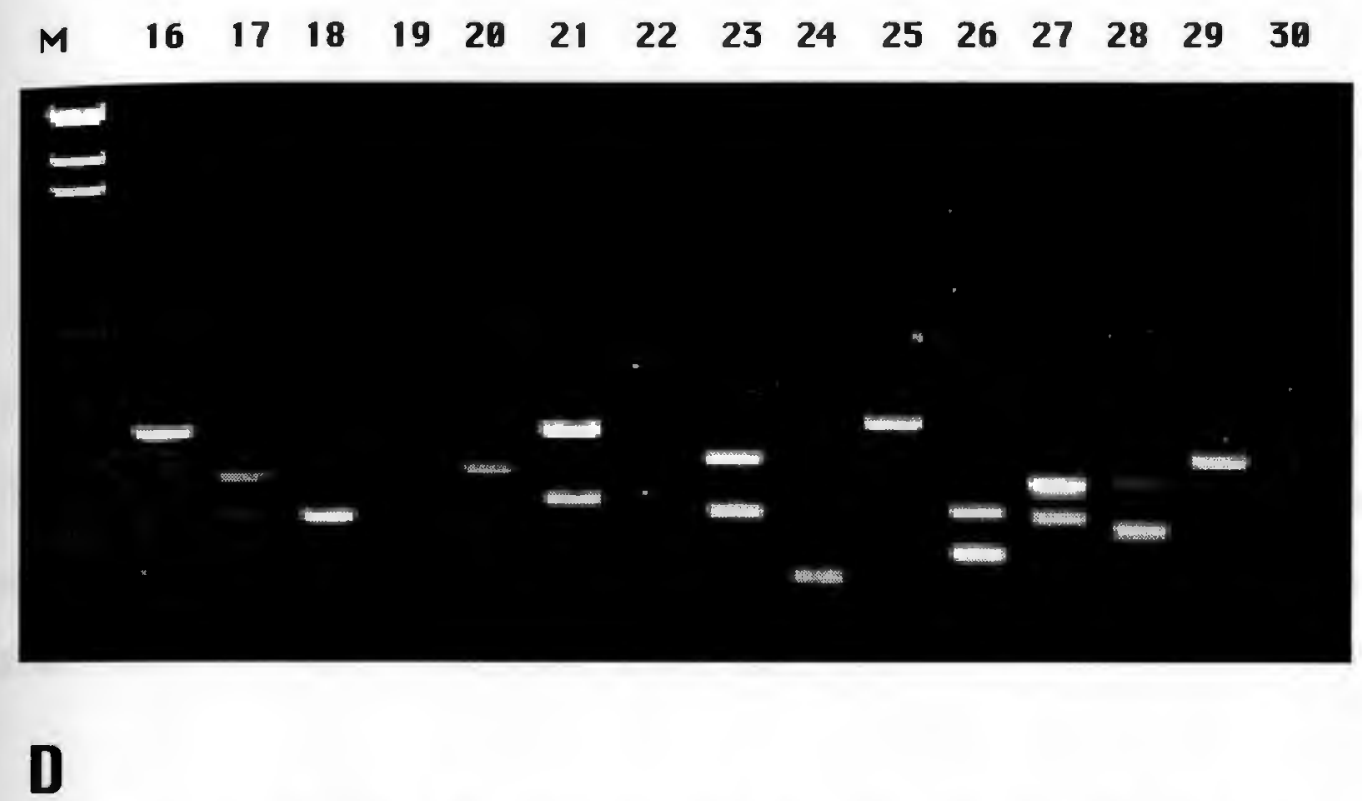

$\begin{array}{lllllllllllllll}16 & 17 & 18 & 19 & 20 & 21 & 22 & 23 & 24 & 25 & 26 & 27 & 28 & 29 & 30\end{array}$

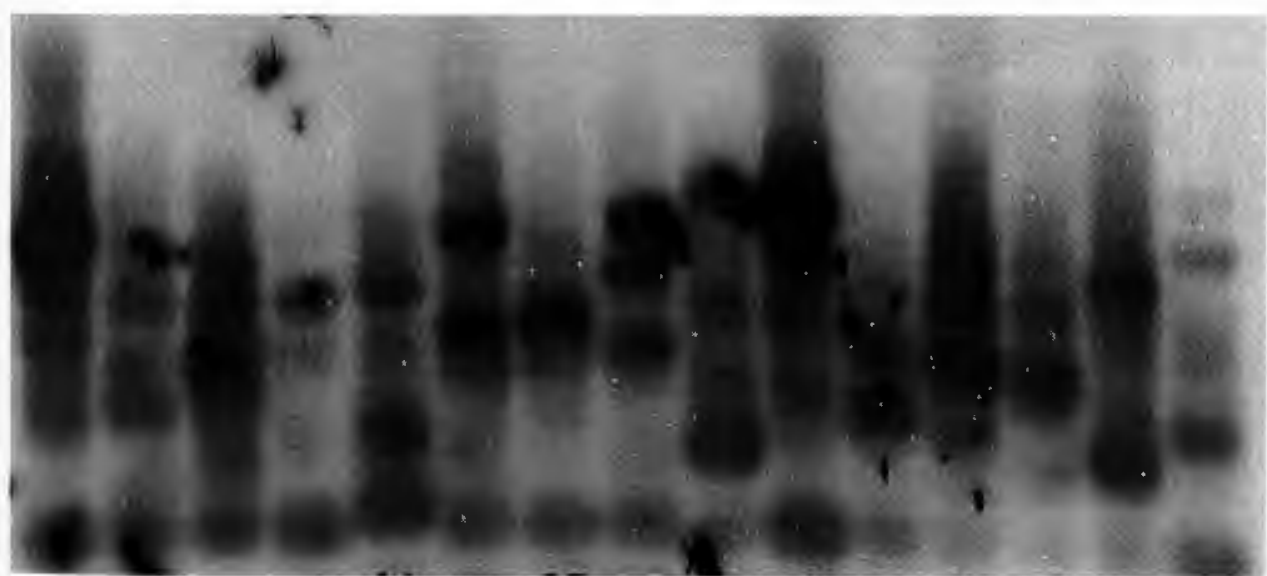


Figure $2 \quad 3^{\circ}$ Screen: Agarose gel electrophoresis of PCR amplification products from the secondary screen. PCR products were separated in a $1.0 \%$ agarose gel, stained with ethidium bromide, and visualized on a UV light box. Samples are (a) 3a-e, 8a-e, 9a-e, 10ae, and 12a-e. (b) 14a-e, 16a-e, 22a-e, 25a-e, and 29a-e. 


$$
\begin{array}{lllll}
3 & 8 & 9 & 10 & 12
\end{array}
$$
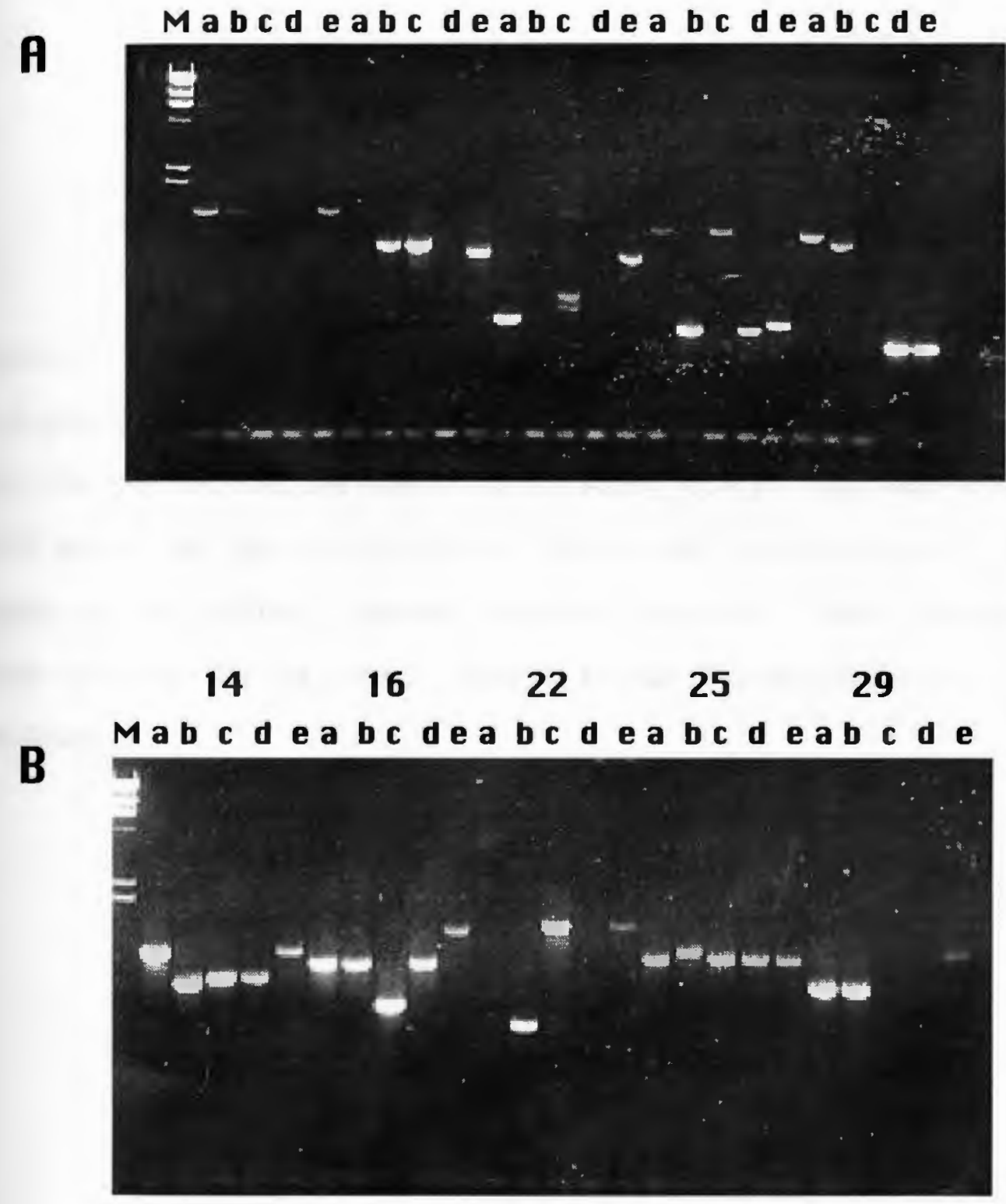
Figure $3 \quad$ (a) $4^{\circ}$ Screen: Agarose gel electrophoresis of PCR amplification products from plaque isolates numbered $3 \mathrm{a}, 3 \mathrm{~b}, 3 \mathrm{e}, 8 \mathrm{~b}, 8 \mathrm{e}, 9 \mathrm{e}, 10 \mathrm{a}, 10 \mathrm{c}, 12 \mathrm{a}, 12 \mathrm{~b}, 14 \mathrm{~b}, 14 \mathrm{c}, 14 \mathrm{~d}$, $22 \mathrm{~b}, 25 \mathrm{a}, 25 \mathrm{~b}, 25 \mathrm{c}, 25 \mathrm{~d}, 25 \mathrm{e}$ from the tertiary screen. PCR products were separated in a $1.0 \%$ agarose gel, stained with ethidium bromide, and visualized on a UV light box. Marker lane (M) is Hind III digested $\lambda$ DNA $(0.5 \mu \mathrm{g})$. (b) $4^{\circ}$ Screen: Southern blot of above gel using Sag2 as a probe. Samples 3e and 10c were chosen for a Northern confirmation. 
A

M 3a 3b 3e $8 b$ 8c 8 e 9 e 10a 10c 12a 12b 14b 14c 14d 22b 25a 25b 25c 25d 25e

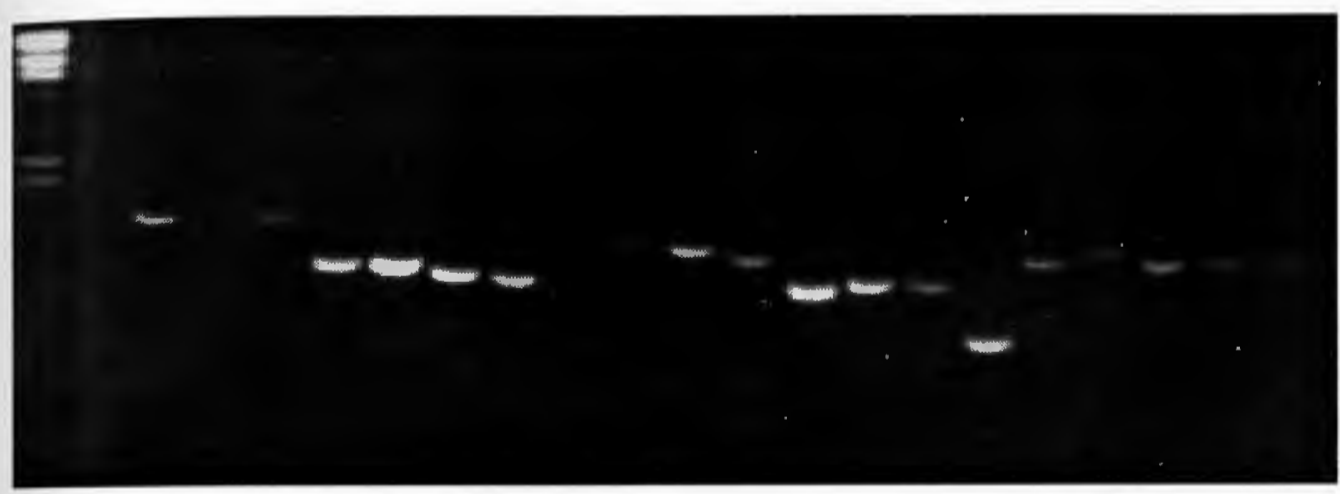

B

3a 3b 3e 8 b $8 c$ ge 9 e 10a 10c 12a 12b 14b 14c 14d 22b 25a 25b 25c 25d 25e

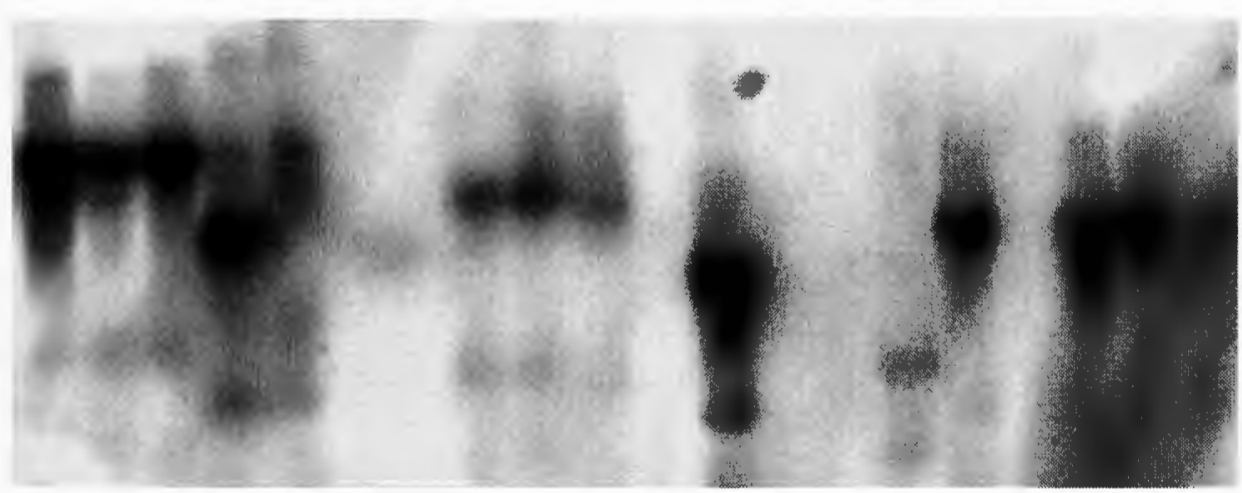




\section{Restriction analysis}

When restriction analysis was carried on pSIC3e and pSIC10c, both showed identical restriction patterns to Sag2. Of the eight restriction enzymes used, only PvuII cut all three clones, which contained two restriction sites (results not shown). pSIC $3 \mathrm{e}$ was estimated to be $1.4 \mathrm{~kb}$ and pSIC $10 \mathrm{c}$ was estimated to be $1.1 \mathrm{~kb}$ (Figures $5 \mathrm{a}$ and $5 \mathrm{~b}$ ). 
Figure 4. (a) Northern blots of cotyledon total RNA populations from different developmental stages. $20 \mu \mathrm{g}$ of total RNA preparations from 5 day (green), 8 day (green), 12day (senescing), and 14 day (senescing) post-germination cotyledons, in addition to 2 day (14+2), 4 day (14+4), and 6 day (14+6) post-decapitation (rejuvenating) cotyledons, were separated on a $1.5 \%$ agarose-formaldehyde gel, transferred to a positively charged nylon membrane and probed hybridized with the following probes:
(a) Sag2
(b) pSIC3e
(c) pSIC10c 
$\begin{array}{lllllll}5 & 8 & 12 & 14 & +2 & +4 & +6\end{array}$

\section{SAG2}

pSIC3e

pSIC10c 
Figure 5. Restriction maps of cloned genes. Insert was released from pBluescript KS+ by digestion with EcoRI, XhoI, and PvuII and run in a 1.0\% agarose gel.
(a) $\mathrm{pSIC} 3 \mathrm{e}$
(b) $\mathrm{pSIC10c}$ 
f) pSIC3e

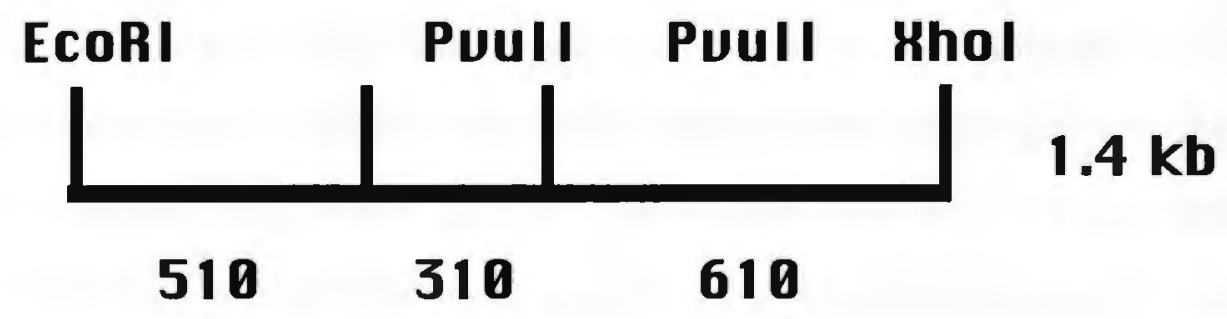

B) pSIC10c

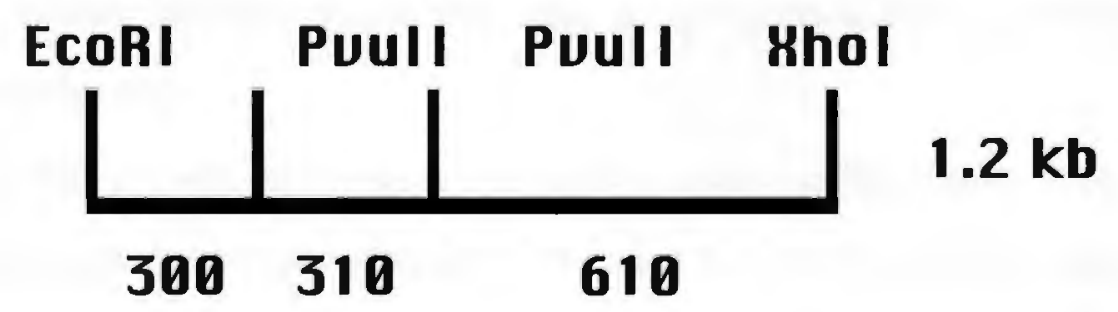




\section{DISCUSSION}

Arabidopsis thaliana has proven to be a useful model system for the study of plant molecular biology because of its' small genome, its' small size, and a rapid life cycle. Sag2 from Arabidopsis thaliana, is a senescence-related clone that codes for a cysteine protease (Hensel et al., 1993). Cysteine proteases have been implicated in all senescing model systems. Sag2 has been shown to be differentially regulated in our soybean cotyledon system. The gene is preferentially up-regulated in expression during cotyledon senescence (Figure 4). Availability of Sag2 homologous gene sequences from soybean will allow for comparisons between Arabidopsis and soybean and better assess the function of this gene during senescence. The cDNA clones, pSIC3e and pSIC10c, are currently being sequenced and used to recover an intact genomic clone from soybean for future studies on the nature of the structure of the gene and its' associated regulatory sequences. An additional benefit of the soybean cotyledon system is that the process of rejuvenation or the reversal of senescence can be investigated. This process is interesting because at the molecular level it does not represent a simple reversal of senescence, but instead a unique developmental process. We have shown that Sag2 is up-regulated during senescence as well as during rejuvenation.

Sag2 and its' soybean homologues are rapidly down-regulated upon decapitation and then gradually accumulate again (Figure 4). Because this gene is so highly regulated it should be an interesting and important gene to study. Further experiments have been completed that show that Sag2 behaves in soybean leaf tissues as in cotyledons (results not shown). Patterns of expression can now be assessed in systems where the normal senescence program has been modified. Male sterile lines $\left(m s_{1}\right.$ and $\left.m s_{2}\right)$ and depodded wild type soybean that do not exhibit senescence or abscission would provide two interesting systems. In addition, evergreen mutants $\left(d_{1} d_{2}, G\right.$, and $\left.G d_{1} d_{2}\right)$ that do not senesce, but abscise normally would also be candidates to assay the expression of Sag2 
and its' soybean homologues. These experiments should provide insight into the regulation of senescence. In addition, comparison of the evergreen mutant patterns of expression against the patterns of expression of depodded or male sterile lines should help define the regulatory differences between senescence and abscission. 


\section{LITERATURE CITED}

Bate NJ, Straus NA, Thompson JE (1990) Expression of chloroplast photosynthesis genes during leaf senescence. Physiologia Plantarum 80: 217-225.

Christofferson RE, Tucker ML, Laties GG (1984) Cellulase gene expression in ripening avocado fruit: The accumulation of cellulase mRNA and protein as demonstrated by cDNA hybridization and immuno-detection. Plant Molecular Biology 3:385391.

Davies KM, Grierson D (1989) Identification of cDNA clones for tomato (Lycopersicon esculentum Mill.) mRNAs that accumulate during fruit ripening and leaf senescence in response to ethylene. Planta 179: 73-80.

DellaPenna D, Alexander DC, Bennett AB (1986) Molecular cloning of tomato fruit polygalacturonase: Analysis of polygalacturonase mRNA levels during ripening. Proceedings of the National Academy of Sciences, USA $83: 6420-6424$

Farrell RE, Jr. (1990) Methodologies for RNA characterization II: Quantitation by northern blot analysis and the S1 nuclease assay. Clinical Biotechnology 2: 107119

Lohman KN, Gan S, Manorama C, Amasino R, Amasino J (1994) Molecular Analysis of natural leaf senscence in Arabidopsis thaliana. Physiologia Plantarum 92: 322-328

McCarty D (1986) A simple method for extraction of RNA from maize tissue. Maize Genetics Cooporation Newsletter 60:61. 
Meyer RCJ, Goldsbrough PB, Woodson WR (1991) An ethylene-responsive flower senescence-related gene from carnation encodes a protein homologous to glutathione s-transferases. Plant Molecular Biology 17: 277-281.

Nooden LD, Leopold AC (eds) (1988) Senescence And Aging In Plants. Academic Press, NY.

Park KY, Drory A, Woodson WR (1992) Molecular cloning of an 1aminocyclopropane-1-carboxylate synthase from senescing carnation petals. Plant Molecular Biology 18: 377-386.

Rundle SJ, Zielinski RE (1991) Organization and expression of two tandamly oriented genes encoding ribulose-1,5-bisphosphate carboxylase/oxygenase activase in barley. Journal of Biological Chemistry 266:4677-4685

Rundle SJ, Zielinski RE (1991) Alterations in barley ribulose-1,5-bisphosphate carboxylase/oxygenase activase gene expression during development and in response to illumination. Journal of Biological Chemistry 266: 14802-14807.

Sabater B, Vera A, Tomas R, Martin M,(1989) Nutrient remobilization, nitrogen metabolism, and chloroplast gene expression in senescent leaves. In Rodriguez $\mathbf{R}$, Sanchez Tames R, Durzan DJ eds, Plant Ageing: Basic and Applied Approaches, Ed Series A Vol 186. Plenum Press, NY, Ny, pp 225-230.

Sambrook J, Fritsch EF, Maniatis T (eds) (1989) Molecular Cloning: A Laboratory Manual, Ed 2 Vol 1-3. Cols Spring Harbor Laboratory Press 
Wang H, Woodson WR (1991) A flower senescence-related mRNA from carnation shares sequence similarity with fruit ripening-related mRNAs involved in ethylene biosynthesis. Plant Physiology 96: 495-502.

Woodson WR (1987) Changes in protein and mRNA populations during senescence of carnation petals. Physiologia Plantarum 71:495-502.

Woodson WR, Lawton KA (1988) Ethyene-induced gene expresion in carnation petals. Plant Physiology 87: 498-503. 


\section{GENERAL DISCUSSION}

Senescence is an important biological process that is characterized by a sequence of biochemical and physiological changes that comprise the final stage of development of a plant. Plant cells undergoing senescence remain viable and metabolically active (Thomas and Stoddart, 1980). Evidence exists to suggest that these changes are in part preprogrammed and under genetic control, however little is known about the molecular mechanisms that control this process. A better understanding of this process will be important for studies relating to: 1) normal cellular differentiation, maintenance, and turnover; 2) plant defense mechanism and the hypersensitive response; and 3) embryogenesis and development. In addition, economic benefits could result from a better understanding of senescence through reduction of post harvest and post production losses as well as an improvement of crop yields.

Many models have been proposed to explain the role of the factors that may initiate senescence. It is well known that many different stimuli or "factors" can trigger the senescence process; it is thought that all these share a common molecular pathway (Smart 1994). These "factors" can be separated into two broad categories; namely, internal factors and external factors. Internal factors include hormones or growth regulators, reproduction, and shading. External factors include temperature, water, pathogens, and minerals. Internal and external factors are thought to share some common control steps in the initiation of the senescence program. The control steps then affect four broad categories of genes that include; 1) catabolic enzymes (pSIC clones are included in this group); 2) stress related proteins; 3) Nutrient remobilization (VSP25 and VSP27 are in this group); and 4) genes involved in abscission. By identifying genes that are up-regulated in expression during senescence, one can then use them as probes to elucidate the signals that regulated the senescence program. 
Soybean has been used as a model system to study senescence (Chang et. al. 1979; Crafts-Brandner and Egli 1987; Huber and Newman 1975; Krul 1974; Marek and Stewart 1992; Nooden 1988; Peterman and Siedow 1985; Skadsen and Cherry 1983). Soybean cotyledons proceed though a process of senescence approximately 14 days after germination. This process has been shown to be reversible by decapitation (Krul, 1974), therefore this system offers the unique ability to study the reversal of senescence or "rejuvenation" which is not possible in other model systems such as Arabidopsis, maize, carnation petals and others. In addition, soybeans are an agriculturally important crop. Furthermore, many soybean lines that have altered patterns of senescence are available. Isogenic evergreen mutants Harosoy with different combinations of single, double, and triple mutants involving the $G, d_{1}$, and $d_{2}$ genes are available. Also male sterile lines, $m s_{1}$ and $m s_{2}$, are available that do not senescence or have leaves that abscise. Finally, depodded wild type soybeans exhibit no senescence or abscission. The use of these mutant and wild type lines allow the processes of senescence and abscission to be examined and studied at the molecular level. The pSIC clones would be candidates for Northern analysis different stages of development during a normal senescence time frame in the lines.

We have used a collection of previously cloned genes to assay their expression during senescence and "rejuvenation" in soybean cotyledons. Different classes of genes were identified as being differentially regulated, these include: 1) catabolic genes such as cysteine protease and ubiquitin ;2) nutrient remobilizing genes i.e., vegetative storage proteins and ; 3) A regulatory gene ACC synthase. These genes serve as molecular markers and can be used to more precisely identify initial stages of senescence and "rejuvenation". It is at the early stages the we expect the regulatory events that control these processes to occur. 
In addition, we have isolated a soybean homologue of Sag2. We can now begin to characterize the soybean gene structure and regulatory sequences. Ultimately it will be interesting to compare these results with the original Sag2 gene.

Future work to investigate the expression of the SIC clones at the whole plant level have begun. Experiments have been carried out that show that the pSIC clones appear to be up-regulated in senescence soybean leaf tissue (results not shown). This data suggests that conclusions that are drawn from the soybean cotyledon system may be applicable to leaf and possibly whole plant senescence. Currently work in has begun to sequence the pSIC clones and recover full length genomic copies. This will provide valuable information about regulatory sequences. 


\section{BIBLIOGRAPHY}

Aharoni N, Liberman M (1979) Patterns of ethylene production in senescing leaves. Plant Physiology 64: 796-800.

Aharoni N, Liberman M (1979) Ethylene as a regulator of senescence in tobacco leaf disks. Plant Physiology 64: 801-804.

Bate NJ, Straus NA, Thompson JE (1990) Expression of chloroplast photosynthesis genes during leaf senescence. Physiologia Plantarum 80: 217-225.

Berry-Lowe SL, McKnight TD, Shah DM, Meagher RB (1982) The nucleotide sequence, expression and evolution of one member of a multigene family encoding the small subunit of ribulose-1,5-bisphosphate carboxylase in soybean. Journal of Molecular and Applied Genetics 1: 483-498.

Bonner J, Varner JE (1976) Plant Biochemistry 3rd ed. Academic Press Inc. New York pg.727.

Borochov A, Woodson, WR (1989) Physiology and biochemistry of flower petal senescence. Horticultural Review 11: 15-43.

Brady CJ (1987) Fruit ripening. Annual Review of Plant Physiology 38:155-178.

Brady CJ (1988) Nucleic acid and protein synthesis. In Nooden LD, Leopold AC, eds, Senescence and ageing in plants. Academic Press, San Diego, pp 147-181. 
Burg S P (1962) The physiology of ethylene formation. Annual Review of Plant Physiology 13: 265-302.

Callow ME, Woolhouse HW (1973) Changes in nucleic acid metabolism in regreening leaves of Perilla. Journal of Experimental Botany 24:285-294.

Carmi A, Koller D (1979) Regulation of photosynthetic activity in the primary leaves of bean (Phaseolus vulgaris L.) by materials moving in the water conducting system. Plant Physiology 64: 285-288.

Carr DJ, Burrows WJ (1966) Evidence of the presence in xylem sap of substances with kinetin-like activity. Life Sciences 5: 2061-2077.

Chang DY, Miksche JP, Dhillon SS (1979) DNA changes involving repeated sequences in senescing soybean Glycine max cotyledon nuclei. Physiologia Plantarum 64: 409-417.

Christofferson RE, Warm E, Laties GG (1982) Gene expression during fruit ripening in avocado. Planta 155:52-57.

Chibnall AC (1939) Protein Metabolism in the Plant, Yale University Press, New Haven.

Chibnall AC (1954) Protein metabolism in rooted runner bean leaves (1954) New Phytologist 53: 31-37. 
Christofferson RE, Tucker ML, Laties GG (1984) Cellulase gene expression in ripening avocado fruit: The accumulation of cellulase mRNA and protein as demonstrated by cDNA hybridization and immuno-detection. Plant Molecular Biology 3:385391.

Crafts-Brandner S.J., Egli D.B. (1987) Sink removal and leaf senescence in soybean. Plant Physiology 85: 662-666.

Cremer F, Dommes J, Van de Walle C, Bernier G (1990) Diurnal rhythmicity in the pattern of mRNAs in the leaves of Sinapis Alba. Plant Physiology 94: 1590-1597.

Crowell DN, Amasino RM (1991) Nucleotide sequence of an iron superoxide dismutase complementary DNA from soybean. Plant Physiology 96: 1393-1394.

Davies KM, Grierson D (1989) Identification of cDNA clones for tomato (Lycopersicon esculentum Mill.) mRNAs that accumulate during fruit ripening and leaf senescence in response to ethylene. Planta 179: 73-80.

DellaPenna D, Alexander DC, Bennett AB (1986) Molecular cloning of tomato fruit polygalacturonase: Analysis of polygalacturonase mRNA levels during ripening. Proceedings of the National Academy of Sciences, USA. $83: 6420-6424$.

Farrell RE, Jr. (1990) Methodologies for RNA characterization II: Quantitation by northern blot analysis and the S1 nuclease assay. Clinical Biotechnology 2: 107 119 
Graham IA, Smith LM, Brown JWS, Leaver CJ, Smith SM (1989) The malate synthase gene of cucumber. Plant Molecular Biology 13: 673-684.

Hensel LL, Grbic V, Baumgarten DA, Bleecker AB (1993) Developmental and agerelated processes that influence the longevity and senscence of photosynthetic tissue in Arabidopsis. The Plant Cell 5: 553-564.

Holdsworth MJ, Bird CR, Ray J, Schuch W, Grierson D (1987) Structure and expression of an ethylene-related mRNA from tomato. Nucleic Acids Research 15: 731-739.

Holdsworth MJ, Schuch W, Grierson D (1987) Nucleotide sequence of an ethylenerelated gene from tomato. Nucleic Acids Research 15: 10600.

Huber DJ, Newman DW (1975) Relationships between lipid changes and plastid ultrastructural changes in senescing and regreening soybean cotyledons. Journal of Experimental Botany 27: 490-511.

Huynh TV, Young RA, Davis RW (1985) Construction and screening of cDNA libraries in lambda gt 10 and lambda gt11. In Glover, DM, ed, DNA cloning: A practical approach, Vol.1 IRL press, NY pp 49-78.

Katagiri K, Tsuji H (1980) Increase in DNA content of primary oat leaves of Phaseolus Vulgaris upon decapitation. Journal of Experimental. Botany 31: 209-222.

Kende H (1971) The cytokinins. Internation Review of Cytology 31:301-338. 
Kende H (1965) Kinetin-like factors in root exudates of sunflower. Proceedings of the National Academy of Sciences, USA 53: 1302-1307.

Klerk H, Van Loon LC (1991) Two-dimensional gel electrophoretic analysis of the changes in soluble proteins during development of primary oat (Avena Sativa) leaves. Journal of Experimental Botany 42: 1295-1304.

Krul WR (1974) Nucleic acid and protein metabolism of senescing and regenerating soybean cotyledons. Plant Physiology 54: 36-40.

Lawton KA, Huang B, Goldsbrough PB, Woodson WR (1989) Molecular cloning and characterization of senescence-related gene expression from carnation flower petals. Plant Physiology 90: 690-696.

Leopold AC, Kawase M (1964) Benzyladenine effects on bean leaf growth and senescence. American Journal of Botany 51: 294-298.

Lindoo SJ, Nooden LD (1977) Studies on the behavior of the senescence signal in Anoka soybeans. Plant Physiology 59: 1136-1140.

Lohman KN, Gan S, Manorama C, Amasino R, Amasino J (1994) Molecular Analysis of natural leaf senscence in Arabidopsis thaliana. Physiologia Plantarum 92: 322-328

Marek LF, Stewart CR (1992) Photosynthesis and photorespiration in presenescent, senescent, and rejuvenated soybean cotyledons. Plant Physiology 98: 694-699. 
McCarty D (1986) A simple method for extraction of RNA from maize tissue. Maize Genetics Cooperation Newsletter 60:61.

Meyer RCJ, Goldsbrough PB, Woodson WR (1991) An ethylene-responsive flower senescence-related gene from carnation encodes a protein homologous to glutathione s-transferases. Plant Molecular Biology 17: 277-281.

Nooden LD, Rupp DC, Derman BD (1978) Separation of seed development from monocarpic senescence in soybeans. Nature 271: 354-356.

Nooden LD, Leopold AC (eds) (1988) Senescence And Aging In Plants. Academic Press, NY.

Nooden LD (1988) The Phenomena of Senecence and Ageing. In Nooden L.D., Leopold A.C., eds, Senescence and Ageing in Plants. Academic Press, San Diego, pp330-368.

Nooden LD, Nooden SM (1985) Effects of morphactin and other auxin transport inhibitors on soybean senescence and pod development. Plant Physiology 78 : 263266.

Nooden, LD (1988) The phenomena of senescence and ageing. In Nooden LD, Leopold AC, eds, Senecence and Ageing in Plants. Academic Press, San Deigo, pp2-51.

Park KY, Drory A, Woodson WR (1992) Molecular cloning of an 1aminocyclopropane-1-carboxylate synthase from senescing carnation petals. Plant Molecular Biology 18: 377-386. 
Peterman TK, Siedow JN (1985) Behavior of lipoxygenase during establishment, senescence, and rejuvenation of soybean cotyledons. Plant Physiology 78: 690695.

Pozsar BI (1980) Peak levels of endogenous cytokinins after decapitation in leaves of leguminous plants: Increase of protein and chlorophyll contents and photosynthetic ${ }^{14} \mathrm{CO}_{2}$ fixation. Acta Agronomica Academiae Scientiarum Hungary 29: 47-49.

Raghothama KG, Lawton KA, Goldsbrough PB, Woodson WR (1991) Characterization of an ethylene-regulated flower senescence-related gene from carnation. Plant Molecular Biology 17: 61-71.

Rapp JC, Mullet JE (1991) Chloroplast transcription is required to express the nuclear genes $r b c S$ and cab. Plastid DNA copy number is regulated independently. Plant Molecular Biology 17: 813-823.

Raz V, Fluhr R (1993) Ethylene signal is transduced via protein phosphorylation events in plants. The Plant Cell 5: 523-530.

Rundle SJ, Zielinski RE (1991) Organization and expression of two tandamly oriented genes encoding ribulose-1,5-bisphosphate carboxylase/oxygenase activase in barley. Journal of Biological Chemistry 266: 4677-4685. 
Rundle SJ, Zielinski RE (1991) Alterations in barley ribulose-1,5-bisphosphate carboxylase/oxygenase activase gene expression during development and in response to illumination. Journal of Biological Chemistry 266: 14802-14807.

Sabater B, Vera A, Tomas R, Martin M,(1989) Nutrient remobilization, nitrogen metabolism, and chloroplast gene expression in senescent leaves. In Rodriguez $\mathbf{R}$, Sanchez Tames R, Durzan DJ eds, Plant Ageing: Basic and Applied Approaches, Ed Series A Vol 186. Plenum Press, NY, Ny, pp 225-230.

Sambrook J, Fritsch EF, Maniatis T (eds) (1989) Molecular Cloning: A Laboratory Manual, Ed2 Vol1-3. Cold Spring Harbor Laboratory Press.

Sato T, Theologis A (1989) Cloning the mRNA encoding 1-aminocyclopropane-1caboxylate synthase, the key enzyme for ethylene biosysnthesis in plants. Proceedings of the National Academy of Scieneces, USA 86: 6621-6625.

Setter TL, Brun WA, Brenner ML (1980) Effect of obstructed translocation on leaf abscissic acid and associated stomatal closure and photosynthetic decline. Plant Physiology 65:1111-1115.

Shibata D, Steczko J, Dixon JE, Hermodson M, Yazdanparast R, Axelrod B (1987) Primary structure of soybean lipoxygenase-1. Journal of Biological Chemistry 262: 10080-10085.

Shibata D, Steczko J, Dixon JE, Andrews PC, Hermodson M, Axelrod B (1988) Primary structure of soybean lipoxygenase-2. Journal of Biological Chemistry 263 : 6816-6821. 
Short JM, Fernandez JM, Sorge JA, Huse WD (1988) Lambda ZAP: A bacteriophage lambda expression vector with in vivo excision properties. Nucleic Acids Research 16: 861-868.

Skadsen RW, Cherry JH (1983) Quantitative changes in In vitro and In vivo protein synthesis in aging and rejuvenated soybean cotyledons. Plant Physiology 71: 861868.

Skoog F, Strong FM, and Miller CO (1965) Cytokinins. Science 148: 531-532.

Skoog F, Hanz HW, Szweykowska AM, Leonard NJ, Carraway JL, Fujii T, Helgenson JD, Loeppky RM (1967) Cytokinin antagonists: synthesis and physiological effects of 7-substituted 3 methyl pyrazolo [4,3-d] pyrimidines. Phytochemistry 12:25.

Slater A, Maunders MJ, Edwards K, Schuch W, Greirson D (1985) Isolation and characterisation of cDNA clones for tomato polygalacturonase and other ripeningrelated proteins. Plant Molecular Biology 5:137-147.

Start WG, Ma Y, Pollacco JC, Hildebrand DF, Freyer GA, Altschuler M (1986) Two soybean lipoxygenase nulls accumulate reduced levels of lipoxygenase transcripts. Plant Molecular Biology 7: 11-23.

Short K, Torrey JG (1972) Cytokinins in seedling roots of pea. Plant Physiology 49: 155-162. 
Theologis A (1992) One rotten apple spoils the whole bushel: the role of ethylene in fruit ripening. Cell 70: 181-184.

Thimann K.V., (1980) The senescence of leaves. In Thimann K.V., ed, Senescence in plants. CRC Press, Boca Raton, pp 85-116.

Thomas H, Stoddart JL (1980) Leaf Senescence. Annual Review of Plant Physiology 31: 83-111.

Thomson WW, Plat-Aloia KA (1987). Ultrastructure and senescence in plants. In Plant Senecence: Is Biochemistry and Physiology, Thomson WW, Nothnagel EA, Huffaker RC eds (Rockville, MD: American Society of Plant Physiologists), pp. 20-30.

Van Der Straeten D, Van Wiemeersch L, Goodman HM (1990) Cloning and sequence of two different cDNAs encoding 1-aminocyclopropane-1-carboxylitte synthase in tomato. Proceedings of the National Academy of Sciences, USA. 87: 4859-4863.

Wang H, Woodson WR (1991) Reversible inhibition of ethylene action and interuption of petal senescence in carnation flowers by norbornadiene. Plant Physiology 89: 434- 438.

Wang H, Woodson WR (1991) A flower senescence-related mRNA from carnation shares sequence similarity with fruit ripening-related mRNAs involved in ethylene biosynthesis. Plant Physiology 96: 495-502. 
WoodsonWR (1987) Changes in protein and mRNA populations during senescence of carnation petals. Physiologia Plantarum 71:495-502.

Woodson WR, Lawton KA (1988) Ethyene-induced gene expresion in carnation petals. Plant Physiology 87: 498-503.

Yenofsky RL, Fine M, Liu C (1988) Isolation and characterization of a soybean (Glycine max) lipoxygenase-3 gene Molecular Genetics (1988) 211:215-222 